\title{
Seasonal heat storage in calcium sulfoaluminate based hardened cement pastes - experiences with different prototypes
}

\author{
${ }^{*}$ Dr. Josef Kaufmann
}

Empa, Swiss Federal Laboratories for Materials Science and Technology Laboratory for Concrete and Construction Chemistry

Überlandstrasse 129

8600 Dübendorf, Switzerland

Phone ++41 (0)58 7654095

Fax $\quad++41(0) 587656935$

Email Josef.Kaufmann@empa.ch

Dr. Frank Winnefeld

Empa, Überlandstrasse 129, 8600 Dübendorf

Phone ++41 (0)58 7654535

Fax $\quad++41(0) 587656935$

Email Frank.Winnefeld@empa.ch

*corresponding author

\footnotetext{
This document is the accepted manuscript version of the following article: Kaufmann, J., \& Winnefeld, F. (2019). Seasonal heat storage in calcium sulfoaluminate based hardened cement pastes - experiences with different prototypes. Journal of Energy Storage, 25, 100850 (12 pp.). https://doi.org/10.1016/j.est.2019.100850

This manuscript version is made available under the CC-BY-NC-ND 4.0

license http://creativecommons.org/1icenses/by-nc-nd/4.0/
} 


\section{Seasonal heat storage in calcium sulfoaluminate based hardened cement pastes - experiences with different prototypes}

Josef Kaufmann, Frank Winnefeld

\section{Abstract}

Seasonal storage of excess solar energy is a key factor for the enhancement of the energy performance of a decentralized energy supply of private homes. Furthermore, thermal heat storage allows to bridge demand or supply gaps and is thought to be an important element to increase the flexibility of future renewable energy supply systems.

Cementitious materials, being widely available, cheap construction materials, have been proposed for thermal heat storage based on the utilization of their relatively high specific heat capacity. Seasonal heat storage in concrete or mortar has been achieved solely by the incorporation of phase change materials (PCM).

In this contribution, special hardened cement pastes based on hydrated calcium sulfoaluminate cements (CSA), containing large amounts of ettringite as main hydrate phase, are proposed as seasonal heat storage material. Combining relatively high storage capacity and moderate loading temperatures $\left(<100^{\circ} \mathrm{C}\right)$ with mechanical performance and low cost they possess significant advantages regarding the application in buildings.

Theoretical ettringite content of fully hydrated blends based on CSA-OPC-gypsum was modeled and based on these results the thermal properties of some variants were studied. Furthermore, hygric characteristics, microstructure, mechanical and thermo-physical properties were derived.

Different prototypes made with CSA-based hardened cement pastes as seasonal storage material ranging from small size to large scale are studied. Construction details and temperature and humidity distributions within a modular $6 \mathrm{~m}^{3}$ ettringite heat storage unit during loading and deloading are presented.

Keywords: seasonal heat storage, ettringite, calcium sulfoaluminate cement, latent heat, concrete, prototype

\section{Introduction}

In the context of an ongoing global warming and saving of natural resources, alternative energy supply for private homes, especially for heating, is an important topic to be addressed. Locally solar energy or heat is available in excess during summer. Especially solar collectors work with high efficiency of 75 to $85 \%$ converting the solar irradiation to heat. Unfortunately the highest heat demand is timely shifted to winter season when at the same time the solar radiation in general is much reduced. Also special weather conditions like fog (e.g. low stratus) or 
snow covering the solar panels may reduce the solar output in some regions. Seasonal heat or energy storage hence would be a key factor for a decentralized energy supply of private homes. For a thermal energy storage system in residences to be effective, heat storage materials should possess a high energy density and moderate loading temperatures [1,2].

Hereby, in most cases it is not necessary and certainly not economical to cover the full heat supply by stored energy. Rather the possibility of bridging demand or supply gaps and increasing the flexibility of future supply systems is of most importance, as renewable energy resources like wind and sun are not available continuously $[3,4]$.

Heat storage is generally based on one of two principal processes: (i) sensible heat storage utilizes the specific heat of a material, which is the heat required to increase its temperature, while (ii) latent heat storage utilizes the change in enthalpy, associated with a phase change of the material. Typical phase changes are hydration-dehydration or melting-freezing processes. Only latent heat storage allows for loss-free storage, while long-term sensible storage requires excellent thermal insulation.

Concrete, being a massive widely available cheap construction material, has been proposed for thermal heat storage based on the utilization of its relatively high specific heat capacity of almost $50 \%$ of that of water. Thermal heat hence may be stored in concrete by heating it to high temperature and/or preventing from temperature loss by insulation [5-7].

However, the possibilities to use concrete as latent heat storage material seem to be limited. The addition of phase change materials (PCMs) like paraffin to cementitious materials is possible [8-11], but in this case, the latent heat storage potential is attributed to the PCM only. The addition of PCM to concrete has the deficiency of a limited amount of PCM that can be added without losing concrete strength and compactness. Additionally PCM are expensive when compared to concrete.

In this study it is shown that a special cement-bonded material containing ettringite as main hydrate phase can be used as latent heat storage material with a relatively high storage capacity $[12,13]$. Ettringite (calcium aluminate trisulfate hydrate, $3 \mathrm{CaO} \cdot \mathrm{Al}_{2} \mathrm{O}_{3} \cdot 3 \mathrm{CaSO}_{4} \cdot 32 \mathrm{H}_{2} \mathrm{O}$ ), one of the hydrate phases of ordinary Portland cement (OPC), has been proposed earlier as possible latent heat storage material by Struble \& Brown (1986) [14]. The heat storage ability is based on hydration/dehydration and conversion of ettringite upon drying to so-called "metaettringite", which contains only 10-13 water molecules per formula unit instead of 32 [15]. Ettringite starts to dehydrate at quite low temperatures $\left(\approx 40-50{ }^{\circ} \mathrm{C}\right)$ and hence is interesting for solar heat storage applications. The enthalpy needed for dehydration is high, about 600 $\mathrm{kJ} / \mathrm{kg}$ ettringite [14] and the process is fully reversible. In hydrated Portland cement concrete ettringite is found in relatively low quantities ( $<15$ mass- $\%$ of the hardened cement paste) and hence a very low energy storage potential results, as there is only a very minor contribution of other cement hydrates. However, there are other cementitious binders besides Portland cements available, which can be used to produce a cementitious, stable building material with a much higher content of ettringite in the hydrated binder matrix. Among the candidates are the calcium sulfoaluminate cements (CSA), which generate ettringite as main hydration product [16]. In this contribution, it is shown how hardened cement pastes made of CSA-cement may be used in a latent heat storage system based on ettringite dehydration/rehydration. 


\section{Concrete as latent heat storage material}

\subsection{Ettringite content in hydrated CSA}

Calcium sulfoaluminate cements (CSA), representing a low carbon dioxide emission alternative to Portland cement $[17,18]$, have been used and standardized in China since about 40 years [19]. A wide range of CSA clinkers exists. They all contain ye'elimite $\left(4 \mathrm{CaO} \cdot 3 \mathrm{Al}_{2} \mathrm{O}_{3} \cdot \mathrm{SO}_{3}\right)$ as main constituent (30-70 mass-\%) and are generally blended with 5-20\% anhydrite or gypsum. Ye'elimite reacts with calcium sulfate (anhydrite, hemihydrate or gypsum) and water according to equation (1) to form ettringite:

$4 \mathrm{CaO} \cdot 3 \mathrm{Al}_{2} \mathrm{O}_{3} \cdot \mathrm{SO}_{3}+2 \mathrm{CaSO}_{4} \cdot x \mathrm{H}_{2} \mathrm{O}+(38-\mathrm{x}) \mathrm{H}_{2} \mathrm{O}$

$\rightarrow 3 \mathrm{CaO} \cdot \mathrm{Al}_{2} \mathrm{O}_{3} \cdot 3 \mathrm{CaSO}_{4} \cdot 32 \mathrm{H}_{2} \mathrm{O}+4 \mathrm{Al}(\mathrm{OH})_{3} ; \mathrm{x}=0,0.5$ or 2

Thermodynamic modelling based on the geochemical speciation code GEMS $[20,21]$ coupled with the Nagra/PSI database [22] and the cement-specific database CEMDATA 18.1 [23] was carried out to calculate the amounts of ettringite present in ternary blends CSA-OPC-gypsum as highlighted in [24] using the phase compositions given in Table 1 and a water/cement ratio of 0.80 . Perovskite, spinel, gehlenite, dolomite and quartz were assumed to be inert, while the other phases were allowed to react with water. Ettringite contents were calculated as g per 100 g hydrated paste (without excess water).

The hydration of binary mixtures of CSA with gypsum yields high contents of ettringite [24, 25], in this case $70 \mathrm{~g}$ per $100 \mathrm{~g}$ (CSA-1/gypsum 68/32) and $80 \mathrm{~g}$ per $100 \mathrm{~g}$ (CSA-2/gypsum 60/40), respectively, see Fig. 1. Even higher ettringite contents may be obtained in ternary mixtures of CSA, Portland cement and gypsum. Calculations show that in such systems ettringite contents of up to $85 \mathrm{~g}$ per $100 \mathrm{~g}$ (CSA-1/OPC/gypsum) and $87 \mathrm{~g}$ per $100 \mathrm{~g}$ (CSA-1/OPC/gypsum), respectively, are possible.

While ye'elimite hydrates fast, it has to be taken into account that it may take months until years to reach hydration degrees close to $100 \%$ for some of the other phases such as belite in CSA [26, 27] or alite originating from the OPC [28], especially if low water water/cement ratios are used. Thus, and due to the fact that a part of the ettringite might be amorphous [29], ettringite contents determined experimentally in binary and ternary systems might be lower, see e.g. [26-30]. 
a) CSA-1

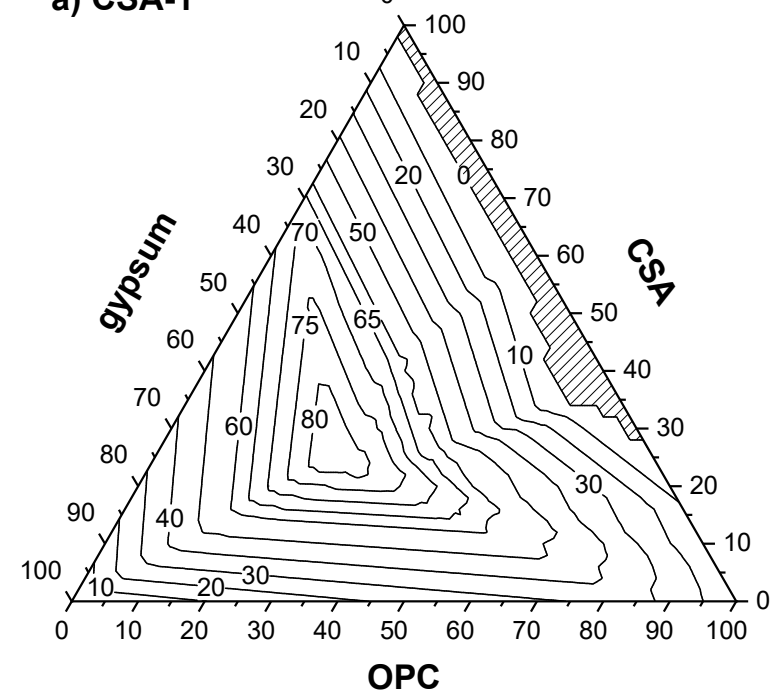

b) CSA-2

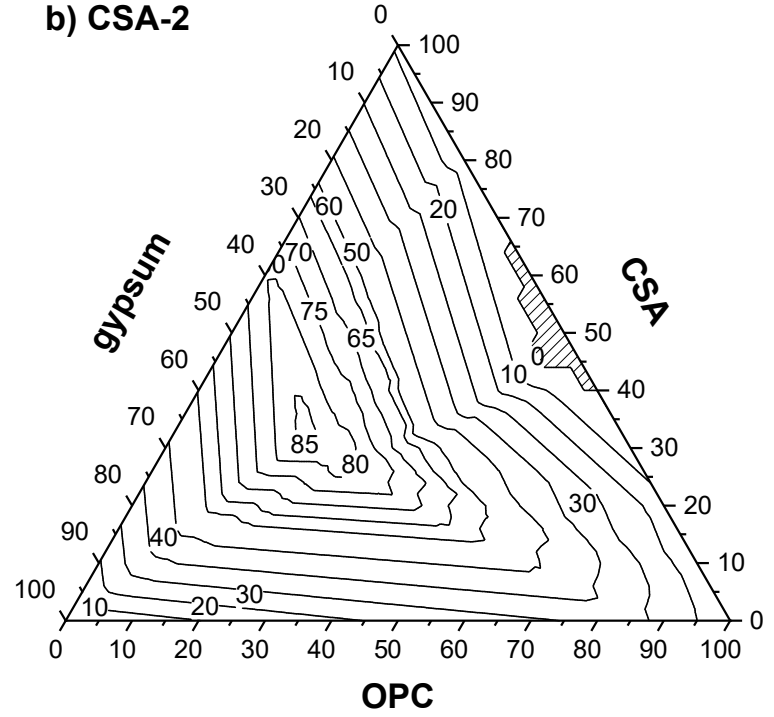

Fig.1 Thermodynamic modelling of the theoretical ettringite content of fully hydrated ternary blends CSA-OPC-gypsum in g per $100 \mathrm{~g}$ solid material; a) CSA-1 and b) CSA-2. In the hatched areas no ettringite is predicted.

\subsection{Ettringite at elevated temperatures}

\subsubsection{Dehydration of ettringite}

The mineral ettringite dehydrates at elevated temperatures (from about $50{ }^{\circ} \mathrm{C}$ ) under dry conditions endothermic by water release to meta-ettringite. The reaction equation of the complete dehydration can be written as:

$3 \mathrm{CaO} \cdot \mathrm{Al}_{2} \mathrm{O}_{3} \cdot 3 \mathrm{CaSO}_{4} \cdot 32 \mathrm{H}_{2} \mathrm{O} \leftrightarrow 3 \mathrm{CaO} \cdot \mathrm{Al}_{2} \mathrm{O}_{3} \cdot 3 \mathrm{CaSO}_{4} \cdot 12 \mathrm{H}_{2} \mathrm{O}+20 \mathrm{H}_{2} \mathrm{O}$

The fully reversible reaction includes an energy balance of $600 \mathrm{~kJ} / \mathrm{kg}$-ettringite $[14,15]$. The degree of the dehydration depends on temperature and water vapor pressure [31].

As can be seen in figure 2 (left) the dehydration temperature decreases on the one hand significantly with a lower water vapor pressure. On the other hand (figure 2, right) dehydration might be mainly governed by the relative humidity (at ambient pressure) of the surrounding air. The relative humidity and the water vapor pressure of hot and humid air can be lowered by drying of the air, for instance by means of condensation processes or by air exchange with colder air. Drying of the air through condensation however involves the supply of large amounts of energy. A low water vapor pressure technically can be achieved by vacuum technology. At a water vapor pressure of 8 mbar the absolute water content in air is $6.3 \mathrm{~g} / \mathrm{m}^{3}$ only, which makes a humidity removal by air exchange or pumping (vacuum) very slow or requires large exchange volumes. At higher water vapor pressure, the water content increases significantly and reaching an absolute water content of about $42 \mathrm{~g} / \mathrm{m}^{3}$ at $45 \mathrm{mbar}$. This can lower the required air exchange rates drastically. Technically dehydration at higher temperatures would be favoured over vacuum pumping unless it would be difficult to reach sufficiently high temperatures for a complete dehydration. 

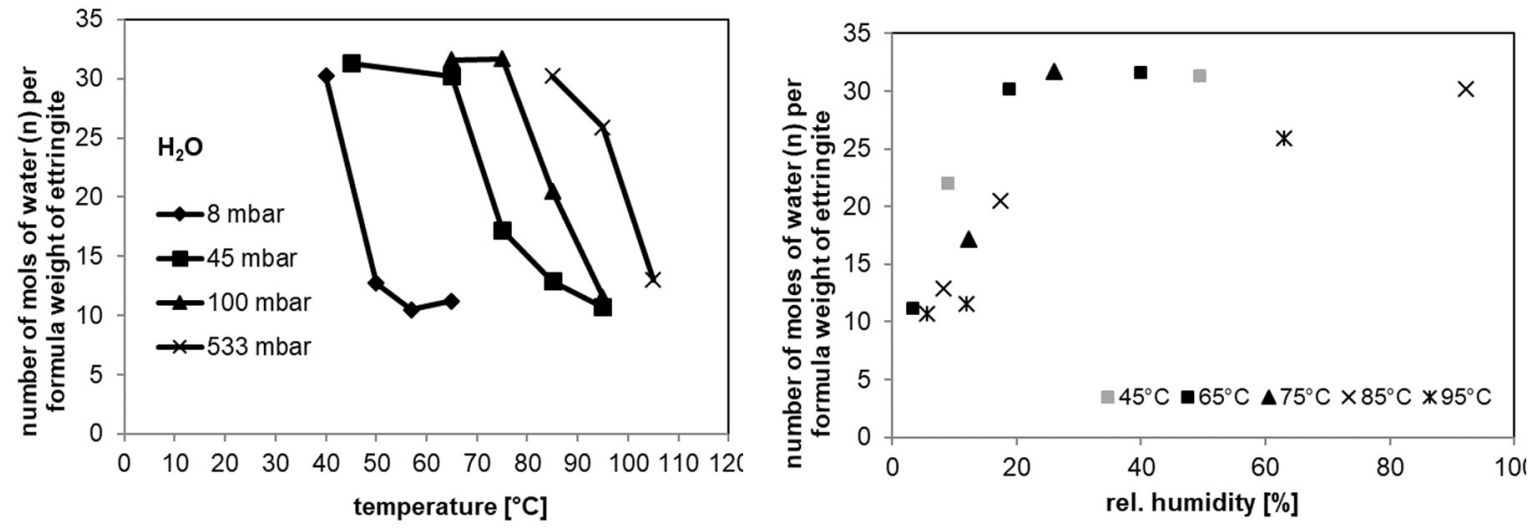

Fig.2 Dehydration of ettringite: Number of mols of water $(n)$ per formula weight of ettringite as a function of $\mathrm{H}_{2} \mathrm{O}$-pressure (left) resp. relative humidity (right) and temperature (adapted from [31]).

\subsubsection{Decomposition of ettringite}

In the previous chapter dehydration of ettringite at elevated temperature was discussed. To make use of this dehydration/hydration process for heat storage, it is important that this process is reversible and that no conversion of ettringite to phases other than meta-ettringite occur. However, under humid condition also chemical decomposition of ettringite to other phases is possible. Far above temperatures of $100^{\circ} \mathrm{C}$, the transition of pure ettringite to monosulfate and calcium sulfatehemihydrate (bassanite) according to equation (3) [32] or to katoite (hydrogarnet) according to equation (4) [33] has been observed.

$$
\begin{aligned}
& 3 \mathrm{CaO} \cdot \mathrm{Al}_{2} \mathrm{O}_{3} \cdot 3 \mathrm{CaSO}_{4} \cdot 32 \mathrm{H}_{2} \mathrm{O} \rightarrow 3 \mathrm{CaO} \cdot \mathrm{Al}_{2} \mathrm{O}_{3} \cdot \mathrm{CaSO}_{4} \cdot 12 \mathrm{H}_{2} \mathrm{O}+2 \mathrm{CaSO}_{4} \cdot 0.5 \mathrm{H}_{2} \mathrm{O}+19 \mathrm{H}_{2} \mathrm{O} \\
& 3 \mathrm{CaO} \cdot \mathrm{Al}_{2} \mathrm{O}_{3} \cdot 3 \mathrm{CaSO}_{4} \cdot 32 \mathrm{H}_{2} \mathrm{O} \rightarrow 3 \mathrm{CaO} \cdot \mathrm{Al}_{2} \mathrm{O}_{3} \cdot 6 \mathrm{H}_{2} \mathrm{O}+3 \mathrm{CaSO}_{4}+26 \mathrm{H}_{2} \mathrm{O}
\end{aligned}
$$

In CSA-based binder systems such phase transitions have been observed under saturated conditions at much lower temperatures below $90^{\circ} \mathrm{C}$ already [34]. These processes must be avoided as the reverse reaction, the formation of ettringite from katoite or monosulfate (reverse reaction according equation $4 \& 5$ ), is highly expansive and may lead to complete loss of structural integrity [35].

Chemical decomposition of ettringite also may take place by carbonation. In presence of carbon dioxide, ettringite may be transformed to calcite, gypsum and aluminum hydroxide.

$3 \mathrm{CaO} \cdot \mathrm{Al}_{2} \mathrm{O}_{3} \cdot 3 \mathrm{CaSO}_{4} \cdot 32 \mathrm{H}_{2} \mathrm{O}+3 \mathrm{CO}_{2} \rightarrow$

$$
3 \mathrm{CaCO}_{3}+3\left(\mathrm{CaSO}_{4} \cdot 2 \mathrm{H}_{2} \mathrm{O}\right)+\mathrm{Al}_{2} \mathrm{O}_{3} \cdot \mathrm{xH}_{2} \mathrm{O}+(26-\mathrm{x}) \mathrm{H}_{2} \mathrm{O}
$$

$x$ is reported to be close to 3 [36]. This process requires the availability of sufficient $\mathrm{CO}_{2}$ gas and hence gas exchange, favourized in dry environment. At the same time the presence of some humidity is necessary as dissolution processes are involved. In completely dry or wet environment this process is very slow. 


\subsection{CSA-based mixtures and their properties}

\subsubsection{Chemical composition of binder components}

Two different CSA-cements were selected regarding the production of samples containing high amounts of ettringite. Table 1 summarizes their mineral phase composition as derived by quantitative X-ray diffraction (QXRD) [37-39]. The main difference between the two CSA cements is the significant amount of belite in CSA-2, while there is a high amount of gehlenite present in CSA-1 instead. In this study mostly binary mixtures were studied where one CSA-cement is mixed with a technical gypsum. Due to the presence of monocalcium aluminate and grossite a slightly higher gypsum addition was used for CSA-1 than for CSA-2. For the ternary blends an ordinary Portland cement CEM I $42.5 \mathrm{~N}$ was used. Water/binder ratio was 0.60 for all mixtures. In this way, hardened cement pastes with high degree of hydration and high ettringite content were produced.

Table 1

Mineralogical analysis (QXRD) of the applied CSA-cements.

\begin{tabular}{|c|c|c|c|c|}
\hline phases & $\begin{array}{c}\text { CSA-1 } \\
\text { (mass-\%) }\end{array}$ & $\begin{array}{c}\text { CSA-2 } \\
\text { (mass-\%) }\end{array}$ & $\begin{array}{c}\text { OPC } \\
\text { (mass-\%) }\end{array}$ & $\begin{array}{c}\text { Gypsum } \\
\text { (mass-\%) }\end{array}$ \\
\hline Ye'elimite & 62.8 & 67.1 & - & - \\
\hline Alite & - & - & 68.7 & - \\
\hline Belite & - & 18.0 & 5.7 & - \\
\hline Mayenite & - & 1.7 & - & - \\
\hline Monocalcium aluminate & 8.1 & - & - & - \\
\hline Grossite & 3.1 & - & - & - \\
\hline Tricalciumaluminate (cubic) & - & - & 2.2 & - \\
\hline Tricalciumaluminate (orthorh.) & - & - & 2.1 & - \\
\hline Ferrite & - & - & 10.2 & - \\
\hline Lime & - & - & 0.2 & - \\
\hline Portlandite & - & - & 1.2 & - \\
\hline Periclase & - & 2.9 & 0.3 & - \\
\hline Anhydrite & - & 1.5 & 0.3 & 3.3 \\
\hline Bassanite & - & - & 1.5 & - \\
\hline Gypsum & - & - & 2.3 & 96.7 \\
\hline Arcanite & - & - & 0.1 & - \\
\hline Aphthitalite & - & - & 0.9 & - \\
\hline Calcite & - & - & 3.3 & - \\
\hline Dolomite & - & - & 0.9 & - \\
\hline Gehlenite & 18.3 & 2.3 & & - \\
\hline Fluorellestadite & - & 5.7 & & - \\
\hline Spinel & 1.8 & - & & - \\
\hline Quartz & - & - & 0.2 & - \\
\hline
\end{tabular}




\subsubsection{Storage density in relation to mix design}

In order to determine the storage energy density, cylindrical samples $(\varnothing=50 \mathrm{~mm}$, height $=50$ $\mathrm{mm}$ ) were produced and stored until an age of $28 \mathrm{~d}$ under water. The amount of gypsum was varied as indicated in table 2 . Only the ternary mixtures lead to highly cracked specimens, whereas the binary mixtures all were widely crack-free with sufficient volumetric stability and strength. From these cylinders small sample of about $7 \times 7 \times 6 \mathrm{~mm}^{3}$ were cut and dried in an oven at $110^{\circ} \mathrm{C}$. Heat development after water addition was measured by isothermal conduction calorimetry. The rehydration (discharge) was carried out in a $20 \mathrm{ml}$ Admix ampoule in an isothermal heat flow calorimeter [40] (TAM Air) by adding $2 \mathrm{ml}$ of demineralized water. The resulting heat flow was measured and the amount of heat released was determined by integration. The density of the samples was determined from the measurement of the volume, on the one hand by measurement, on the other hand to control also by weighing above and below water, and from the determination of the dry weight.

From the resulting cumulative heat (after $60 \mathrm{~min}$ ) the storage density (heat per sample volume, dry density $1.22 \mathrm{~g} / \mathrm{cm}^{3}$ ) as given in table 2 is calculated for the different mixtures. Highest densities are obtained for the binary gypsum-CSA systems with maximum amount of gypsum for optimum ettringite formation. The ternary systems perform not as good as expected, probably due to lower than calculated degree of hydration [41].

Table 2 Storage densities as measured by calorimetry after drying at $110^{\circ} \mathrm{C}$ $(w / b=0.60)$.

\begin{tabular}{lcccc}
\hline & storage density $\left[\mathrm{kWh} / \mathrm{m}^{3}\right]$ & dev. & CSA/G/OPC & description \\
\hline CSA1-1 & 59 & 3 & $75 / 25 / 0$ & $-6 \%$ gypsum \\
CSA1-2 & 61 & 4 & $72 / 28 / 0$ & $-3 \%$ gypsum \\
CSA1-3 & 69 & 8 & $69 / 31 / 0$ & \\
CSA1-T & 58 & 2 & $40 / 40 / 20$ & \\
\hline CSA2-1 & 64 & 4 & $80 / 20 / 0$ & $-6 \%$ gypsum \\
CSA2-2 & 66 & 2 & $77 / 23 / 0$ & $-3 \%$ gypsum \\
CSA2-3 & 66 & 3 & $74 / 26 / 0$ & \\
CSA2-T & 58 & 3 & $43 / 34 / 23$ & \\
\hline
\end{tabular}

\subsubsection{Storage density and mass balance in relation to different drying levels}

For mixture CSA1-2 a more detailed analysis of the storage material was executed. Mass balance at different drying stages was studied (see table 3 ) and compared to the storage density at the respective drying level.

As the condensation of water vapor leads to the liberation of the condensation heat, upon rehydration with water vapor (sorption) an additional energy amount due to condensation may be made accessible, besides the recrystallization energy, for energy storage [42]. A theoretical sorption energy was derived (table 3). It has to be mentioned that sorption processes are favoured in materials with rather narrow pores as there adsorption and Kelvin condensation at 
low water vapor pressure are sufficiently efficient. Additionally, diffusion processes are relevant. In relative dense materials sorption may become very slow.

Table 3 Storage density data for resaturation with water and vapor (CSA1-2).

\begin{tabular}{|c|c|c|c|c|}
\hline $\begin{array}{c}\text { Conditioning } \\
\left.\text { temperature }{ }^{*}\right) \\
{\left[{ }^{\circ} \mathrm{C}\right]} \\
\end{array}$ & $\begin{array}{c}\text { Conditioning } \\
\text { rel. humidity") } \\
\\
{[\%]} \\
\end{array}$ & $\begin{array}{c}\text { Water content relative } \\
\text { to dry weight }\left(110^{\circ} \mathrm{C}\right) \\
{\left[\mathrm{kg} / \mathrm{m}^{3}\right]}\end{array}$ & $\begin{array}{c}\text { Storage density*) } \\
{\left[\mathrm{kWh} / \mathrm{m}^{3}\right]} \\
\end{array}$ & $\begin{array}{c}\text { Theoret. sorption energy } \\
\left.\text { density }{ }^{* * *}\right) \\
{\left[\mathrm{kWh} / \mathrm{m}^{3}\right]}\end{array}$ \\
\hline 20 & 100 & 418 & 0 & 325 \\
\hline 50 & 12.5 & 217 & 6 & 193 \\
\hline 60 & 8 & 55 & 22 & 75 \\
\hline 70 & 5.5 & 48 & 45 & 47 \\
\hline 80 & 3.5 & 31 & 49 & 32 \\
\hline 110 & 0 & 0 & 61 & 0 \\
\hline
\end{tabular}

*) conditioning in air circulated furnace (ambient $20^{\circ} \mathrm{C} / 60 \% \mathrm{RH}=14 \mathrm{mbar}$ )

${ }^{*}$ ) amount of heat that is recovered after drying at the indicated conditioning temperature and subsequent resaturation with liquid water.

${ }^{* * *}$ ) amount of heat (inclusive condensation heat) that is recovered after complete drying at $110^{\circ} \mathrm{C}$ and subsequent partial resaturation with the amount of water vapor corresponding to the weight difference to complete drying (at $\left.110^{\circ} \mathrm{C}\right)$.

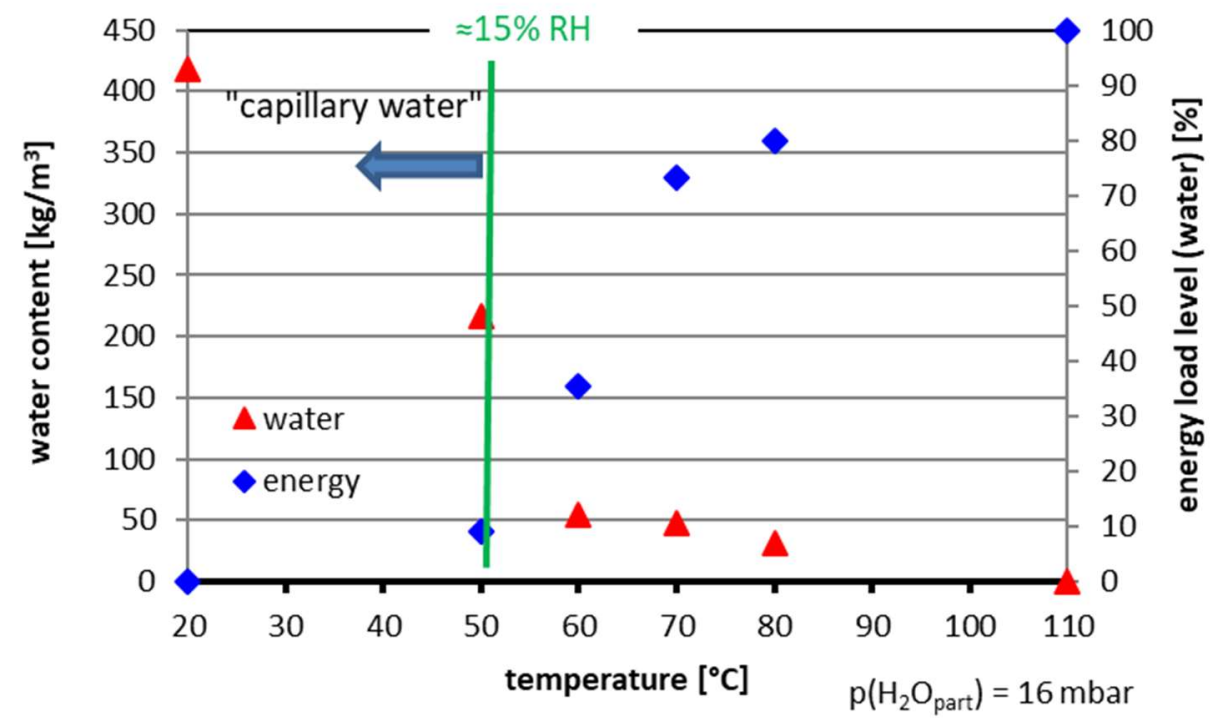

Fig. 3 Water content in relation to completely dry samples $\left(110^{\circ} \mathrm{C}\right)$ and energy load level (amount of heat that is recovered when resaturated with liquid water relative to maximum heat that is recovered upon resaturation with liquid water after drying at $110^{\circ} \mathrm{C}$ ) after drying at the indicated conditioning temperature and subsequent resaturation with liquid water (CSA1-2).

In figure 3 (based on water content and storage energy data in table 3 ) the energy load levels, the relative amount of heat that is released upon rehydration with liquid water of dried (at $110^{\circ} \mathrm{C}$ ) CSA-based hardened cement paste, and the water content in function of the drying temperature are plotted. It can be seen that up to a drying (dehydration) below $50^{\circ} \mathrm{C}$ almost no 
heat can be stored, but relatively high amounts of water are removed and hence the conversion of ettringite to meta-ettringite hardly occurs. It can be concluded that a high amount of the water that is removed by drying at $50^{\circ} \mathrm{C}$ is capillary water, i.e. water that is not bound chemically, but is entrapped in the pore system of the hardened cement pastes. When liquid water is used for resaturation, most of the water is capillary water that does not contribute (without including evaporation/condensation heat) to energy storage.

Mercury intrusion porosimetry data (figure 4, table 4, samples dried at $110^{\circ} \mathrm{C}$ ) reveal that the pore system of the studied CSA-based hardened cement pastes is relatively coarse with high pore volumina. The connected pores (excluding ink-bottle type pores) can be identified in a second mercury intrusion cycle [43]. It can be concluded that the pores larger than $300 \mathrm{~nm}$ in radius, representing more than $5 \mathrm{Vol} .-\%$, mostly are connected to the surface and form a rather transparent transport system for water. This means that at moderate relative humidities high diffusion rates are possible, but also that limited only Kelvin condensation can be expected.

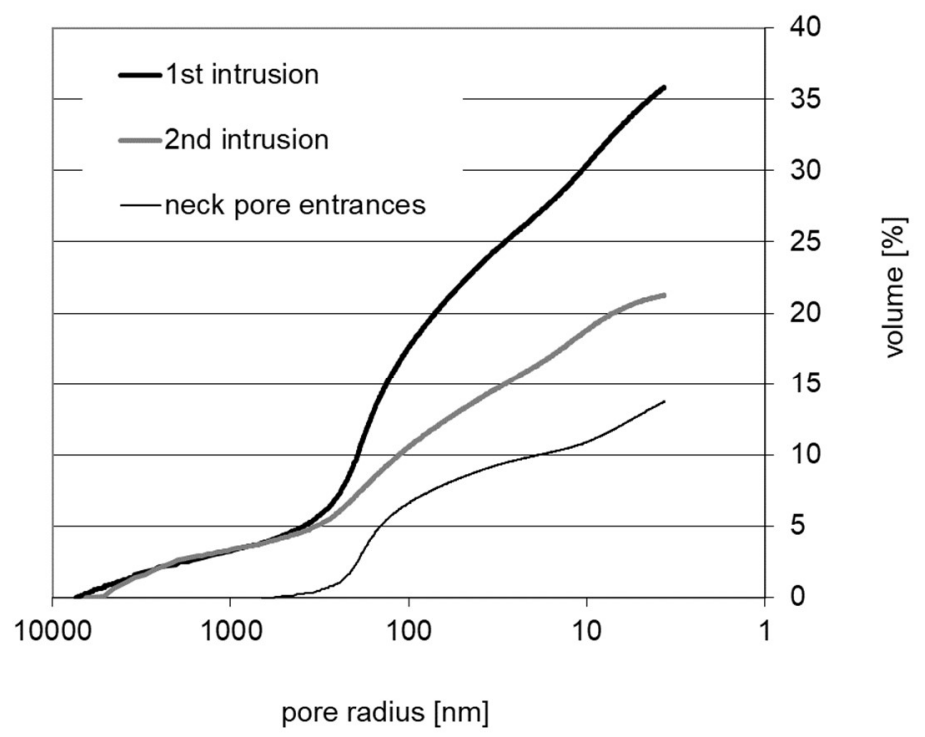

Fig. 4 Pore size distribution of mix CSA1-2 (110 C-dry samples).

\subsubsection{Other physical properties}

The CSA-based storage material is largely open-pored, which facilitates steam and water transport. To be able to estimate its sorption behavior, simple storage and drying experiments were carried out which are reported here, since the storage principle is based on dehydration (charge) and rehydration (heat release - discharge). Water saturated samples (CSA1-2) of $100 \times 20 \times 12 \mathrm{~mm}^{3}$ were dried in different climate conditions. The water loss in function of time is plotted in figure 5. Furthermore, the sorption behavior of completely dried samples (drying at $110^{\circ} \mathrm{C}$ ) in different climate conditions was studied. The water uptake in function of time is plotted in figure 6 . The obtained data reveals that drying processes at small sample size are relatively fast due to the rather porous system, while sorption processes require much more time. While equilibrium values are independent of sample size, the timely distribution of drying and saturation is strongly related to it. It quickly becomes clear that at large scale, the dehydration of ettringite containing hardened cement pastes on the one hand requires the removal of large 
quantities of water and on the other hand the desiccation and the humidification processes get somewhat slow.

Additionally further physical parameters that are important for the material characterization are provided in table 4.

Table $4 \quad$ Other physical properties of mixture CSA1-2.

\begin{tabular}{|c|c|c|c|}
\hline $\begin{array}{l}\text { thermal conductivity } \lambda[\mathrm{W} / \mathrm{mK}] \\
\text { (Norm SN EN 12664:2001) }\end{array}$ & $\begin{array}{l}\text { water saturated at } 20^{\circ} \mathrm{C} \text { : } \\
\text { after drying at } 50{ }^{\circ} \mathrm{C} \text { : } \\
\text { after drying at } 110^{\circ} \mathrm{C} \text { : }\end{array}$ & $\begin{array}{l}0.61 \\
0.44 \\
0.13\end{array}$ & slabs $500 \times 500 \times 20 \mathrm{~mm}^{3}$ \\
\hline oxygen diffusivity coefficient $[45]\left[\times 10^{-8} \mathrm{~m}^{2} / \mathrm{s}\right]$ & after $7 \mathrm{~d}$ at $20^{\circ} \mathrm{C} / 35 \% \mathrm{RH}:$ & $10.7+/-0.9$ & cores $\varnothing=100 \mathrm{~mm} / \mathrm{h}=50 \mathrm{~mm}$ \\
\hline total porosity (Hg-porosity) [Vol.-\%] & $\begin{array}{l}\text { after drying at } 50^{\circ} \mathrm{C} \text { : } \\
\text { after drying at } 110^{\circ} \mathrm{C}\end{array}$ & $\begin{array}{l}24.9 \\
35.9\end{array}$ & small pieces about $3 \mathrm{~g}$ \\
\hline Compressive strength at 28d [MPa] & & 30.8 & cubes $150 \times 150 \times 150 \mathrm{~mm}^{3}$ \\
\hline Shrinkage of saturated samples $[\mathrm{mm} / \mathrm{m}]$ & $\begin{array}{l}\text { by drying at } 50^{\circ} \mathrm{C}: \\
\text { by drying at } 110^{\circ} \mathrm{C}:\end{array}$ & $\begin{array}{l}-1.40 \\
-2.00\end{array}$ & prisms ca. $20 \times 10 \times 150 \mathrm{~mm}^{3}$ \\
\hline
\end{tabular}

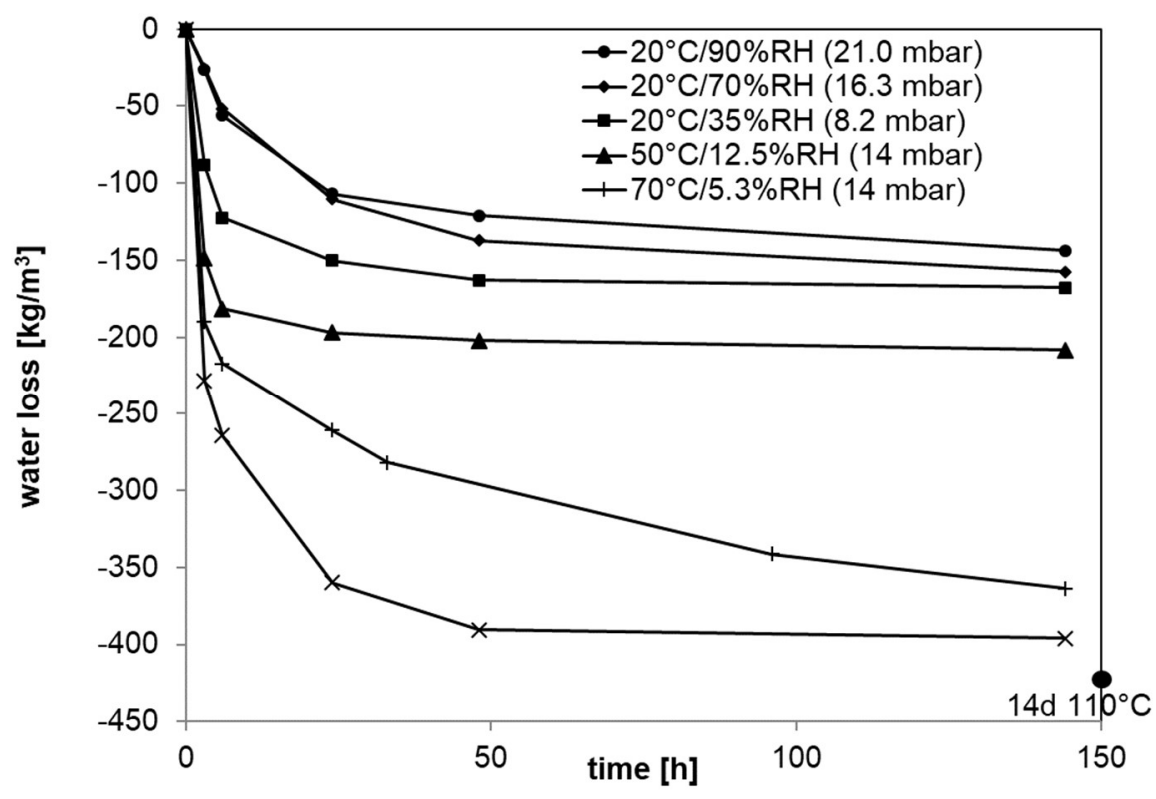

Fig. 5 Water loss of saturated samples (at $20^{\circ} \mathrm{C}$ ) in different climates (CSA1-2). 


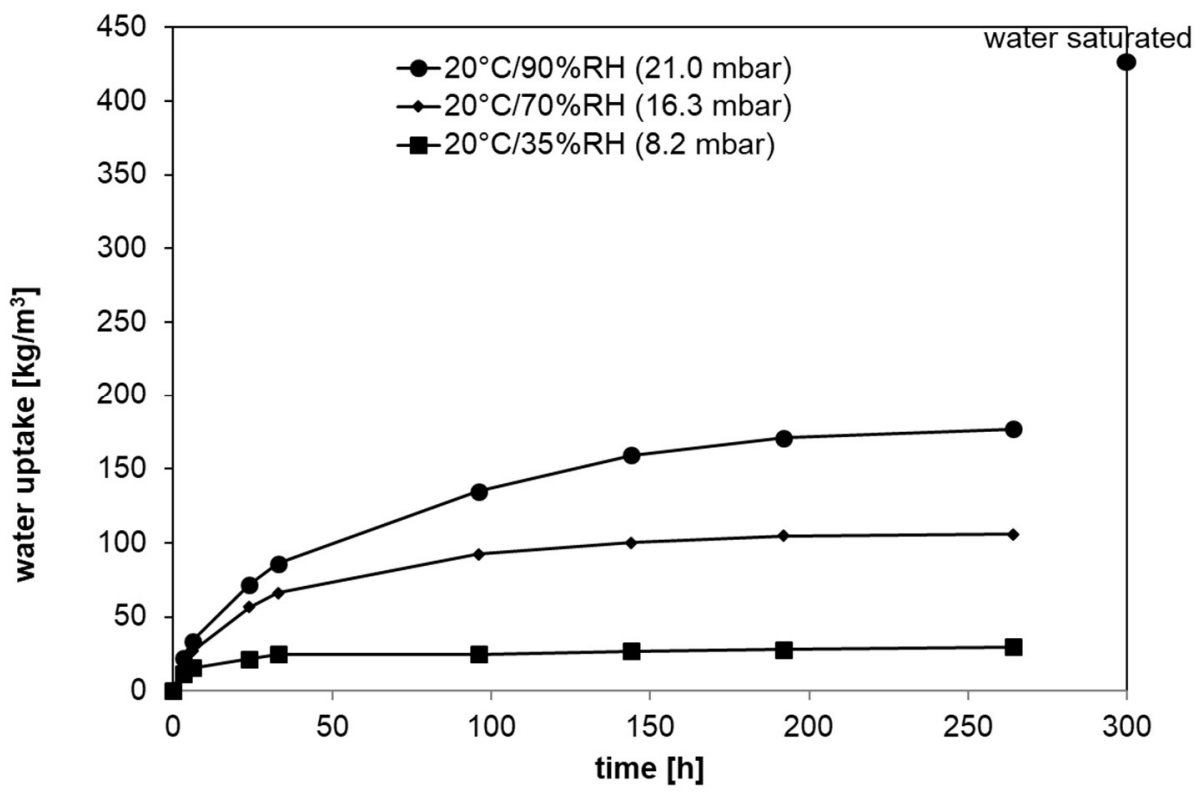

Fig. 6 Water uptake of completely dried $\left(110^{\circ} \mathrm{C}\right)$ samples in different climates (CSA1-2).

\section{Prototype set-ups}

\subsection{Small scale prototypes}

In order to test different concepts and to gain first experience, two different small scale storage prototypes i) suction: rehydration with liquid water ii) sorption: rehydration with water vapor were studied. First, slabs of hardened cement paste of mixture CSA1-2 of the dimension $50 \times 40 \times 3 \mathrm{~cm}^{3}$ were fabricated. Each plate contained 6 round recesses (half circle with diameter $1 \mathrm{~cm}$ ) so that when two plates were placed one next to the other a cylindrical recess resulted. For these trials all plates were then dried (loaded) at $110^{\circ} \mathrm{C}$ in an oven for one week.

For the suction prototype (figure $7 a$ ), 6 of such dried plates were placed within a thermally insulated box (insulation with $5 \mathrm{~cm}$ extruded polystyrene (XPS)). Water was added continuously to keep filled the recess holes. By means of a thermocouple placed at the center of the arrangement the temperature rise in function of time was registered. A very steep temperature rise was observed upon water addition $\left(20^{\circ} \mathrm{C}\right)$ to reach more than $80^{\circ} \mathrm{C}$ within less than one hour after water addition, despite poor thermal insulation of the arrangement.

For the sorption prototype (figure $7 \mathrm{~b}$ ), 4 of such plates were cut to 4 pieces of $50 \times 10 \times 3 \mathrm{~cm}^{3}$. By sawing additional cuts were introduced and more surface was created, so that the distance within these plates to reach one surface was less than $0.5 \mathrm{~cm}$ at each point. This was in order to provide sufficient access for the water vapor and reducing diffusion time. These plates were arranged in a way that a storage module (thermally insulated with $5 \mathrm{~cm}$ XPS) of $200 \times 10 \times 10$ $\mathrm{cm}^{3}$ resulted. The plates for the module were pre-dried at $110^{\circ} \mathrm{C}$ and then the sorption module was placed in a climate room at $20^{\circ} \mathrm{C} / 90 \% \mathrm{RH}\left(\mathrm{p}_{\mathrm{H} 2 \mathrm{O}} \approx 21 \mathrm{mbar}\right.$ ). By means of a ventilator humid air was forced to flow through the module at a speed of $2 \mathrm{~m} / \mathrm{s}$. The above mentioned recesses were forming flow paths for the air. The temperature of the outflowing air at the opposite front 
was measured by means of a thermocouple. Even without ventilation a small temperature rise compared to the room temperature was observed. When ventilation started a maximum temperature rise of about $15{ }^{\circ} \mathrm{C}$ was obtained for the outflowing air.

a) Suction
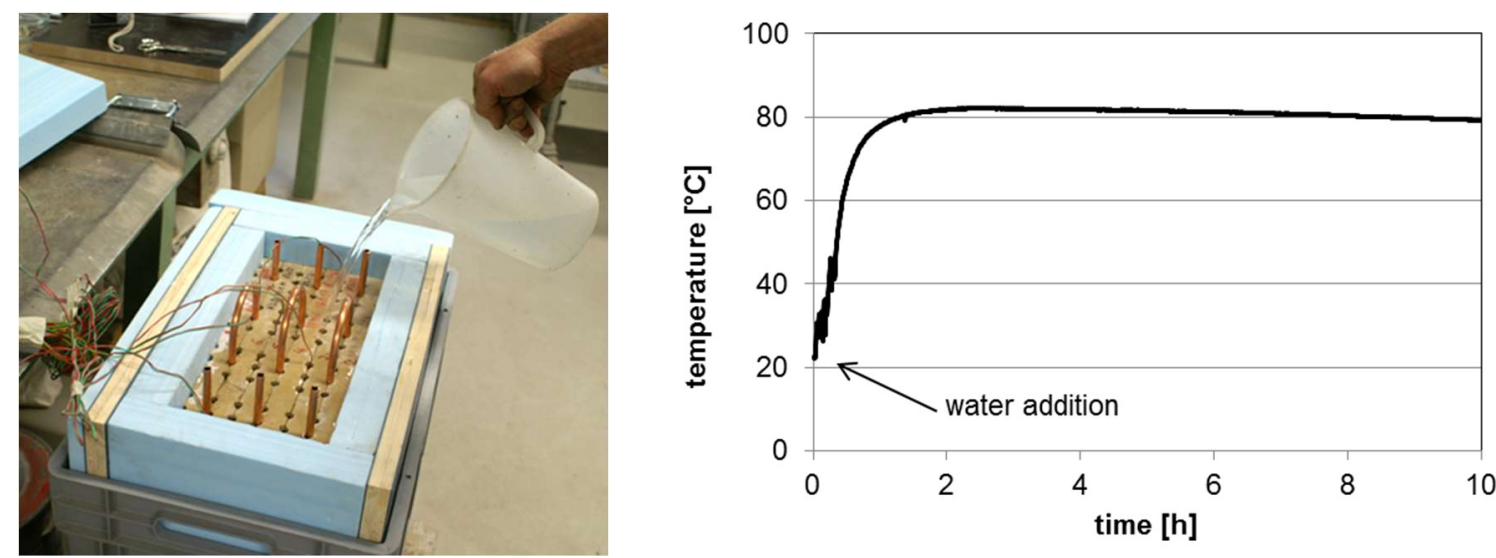

b) Sorption
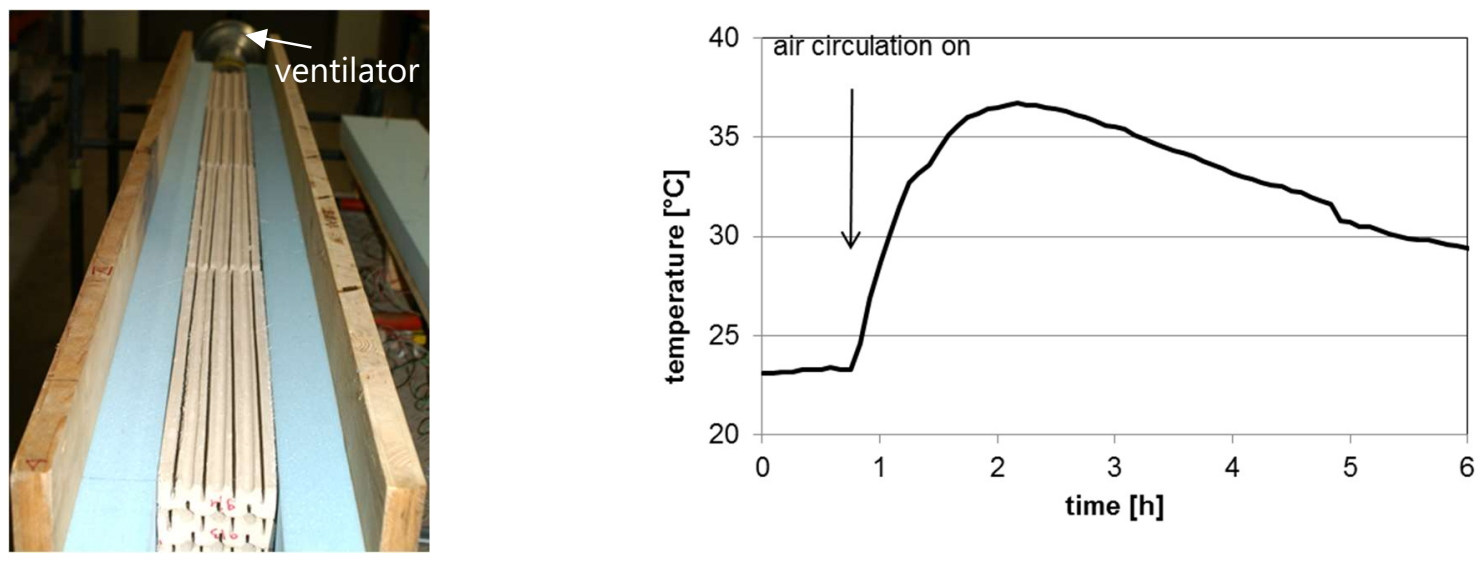

Fig. 7 Small scale simple storage prototypes:

a) suction: water addition to slabs pre-dried at $110^{\circ} \mathrm{C}$ (CSA1-2 6 slabs of $50 \times 40 \times 30$ $\mathrm{cm}^{3}$ ) and resulting temperature rise as a function of time

b) sorption: sorption in $20^{\circ} \mathrm{C} / 90 \% \mathrm{RH}$ of slabs pre-dried at $110^{\circ} \mathrm{C}(\mathrm{CSA} 1-2,4$ times 4 slabs of $50 \times 10 \times 3 \mathrm{~cm}^{3}$ ) and resulting temperature rise as a function of time at a wind speed of $2 \mathrm{~m} / \mathrm{s}$. (half opened in the picture for better presentation) 


\subsection{Large scale prototype \\ 3.2.1 General set-up}

In order to demonstrate the large scale feasibility, a much larger prototype of $6 \mathrm{~m}^{3}$ based on CSA2-2 was to be realized in a house (holiday residence) in Seelisberg (Switzerland). The basic concept should comprise a cost-efficient simple construction process with the ability of post-placing the heat storage unit into an existing building. To maintain simplicity, this prototype should neither include vacuum dehydration nor rehydration by a sorption process, which would have the prerequisite of the access to a sufficient vapor source not being supported on site. Rehydration was hence by simple liquid water addition.

A modular set-up was chosen. Storage modules made of CSA-based hardened cement pastes of $1 \times 1 \times 0.25 \mathrm{~m}^{3}$ each were prefabricated (figure $8 \mathrm{a}$ ). For such, a special formwork containing all the necessary recesses was constructed in which copper tubes with 7 loops (inner diameter $16 \mathrm{~mm}$, outer diameter $18 \mathrm{~mm}$ ) for heat exchange from the solar collector (loading, summer) respectively to the house heating system (deloading, winter) were placed. The CSA-pastes were mixed in a conventional concrete mixer, however the water was added prior to the cement, as powder dispersion in this way is much favorable. Some macro-synthetic and fine glass fibers were added to the mixture CSA2-2 in order to provide additional ductility and crackbridging properties as well as to support the mixing process. The very fluid mixture finally was poured into the formwork with the copper tubes. During hydration some plastic foil preventing from water loss was placed. This was important as the temperature rise was up to $90^{\circ} \mathrm{C}$ during the hydration process and thus evaporation of mixing water needed to be avoided. After 1 day sufficient strength was obtained for demoulding. The obtained elements of hardened CSAconcrete contained different recesses (Fig 8a): a) 2 recesses for transport and lifting by means of a forklift b) 3 recesses for water addition in a cascade system at the top (groves and holes for the access to the lower level) c) recesses for tube connection front side (recesses for tube fittings). Eight such elements were piled up ( $2 \mathrm{~m}^{3}$, Fig. $\left.8 \mathrm{~b}\right)$ and three of such piles were put in a row (Fig. $8 d$ ). The heat exchange tubes of each module were connected by means of fittings (fig. 8c) and flexible short metal tubes to form one single loop through the whole storage unit having one inflow (top left) and one outflow (bottom left). In this way a heat exchange surface to/from the concrete of $1.13 \mathrm{~m}^{2} / \mathrm{m}^{3}$, totally about $6.8 \mathrm{~m}^{2}$, was provided. The elements finally were placed in the garage of the home. The concrete unit furthermore had to be equipped with a vapor barrier for allowing a controlled air flow within the unit and for preventing humidity exchange with the environment. This was provided by means of a modular construction of stainless steel sheets $(1.5 \mathrm{~mm}$ thickness) that could be fitted to form a box surrounding the concrete storage unit. In the scope of the presented work structural stability was important. Certainly much cheaper foil solutions might be developed for such purpose. Obviously the storage unit also had to be thermally insulated. This was provided by $25 \mathrm{~cm}$ foam glass (bottom) and $25 \mathrm{~cm}$ glass wool (side/top). 
a)

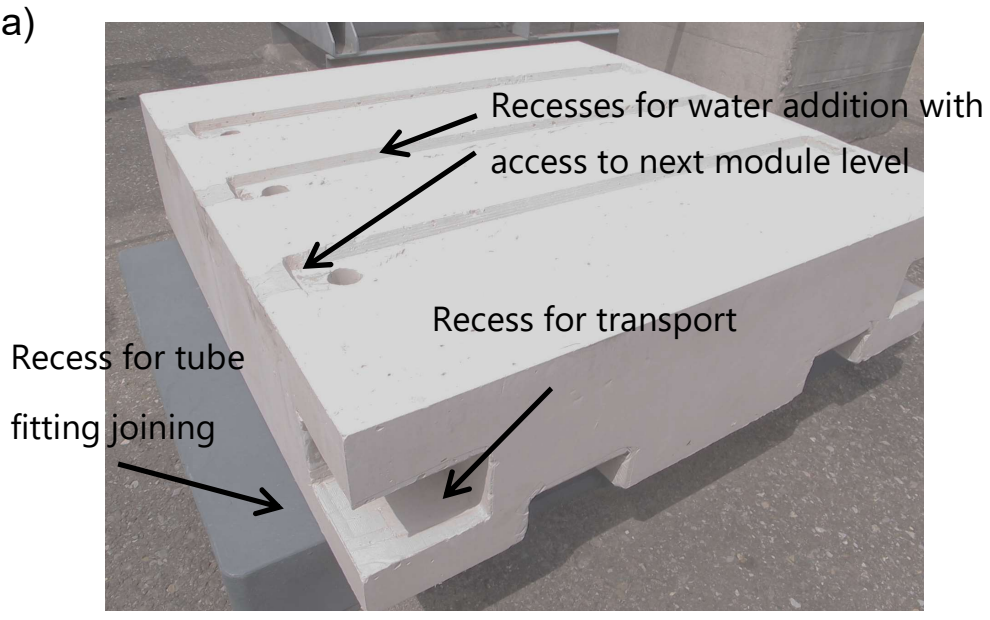

b)

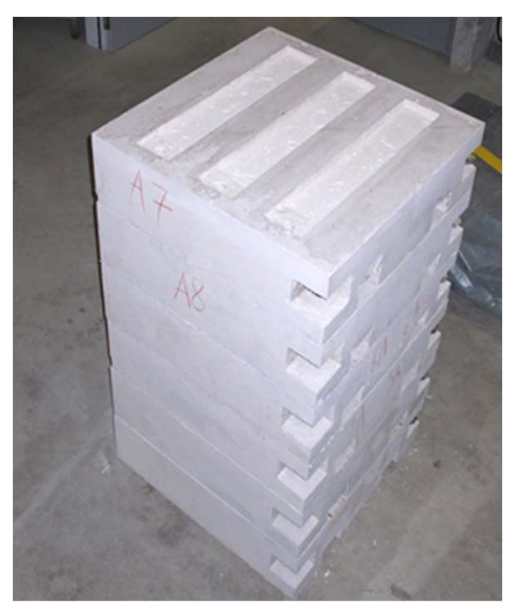

thermal isolation

embedded heat

c)
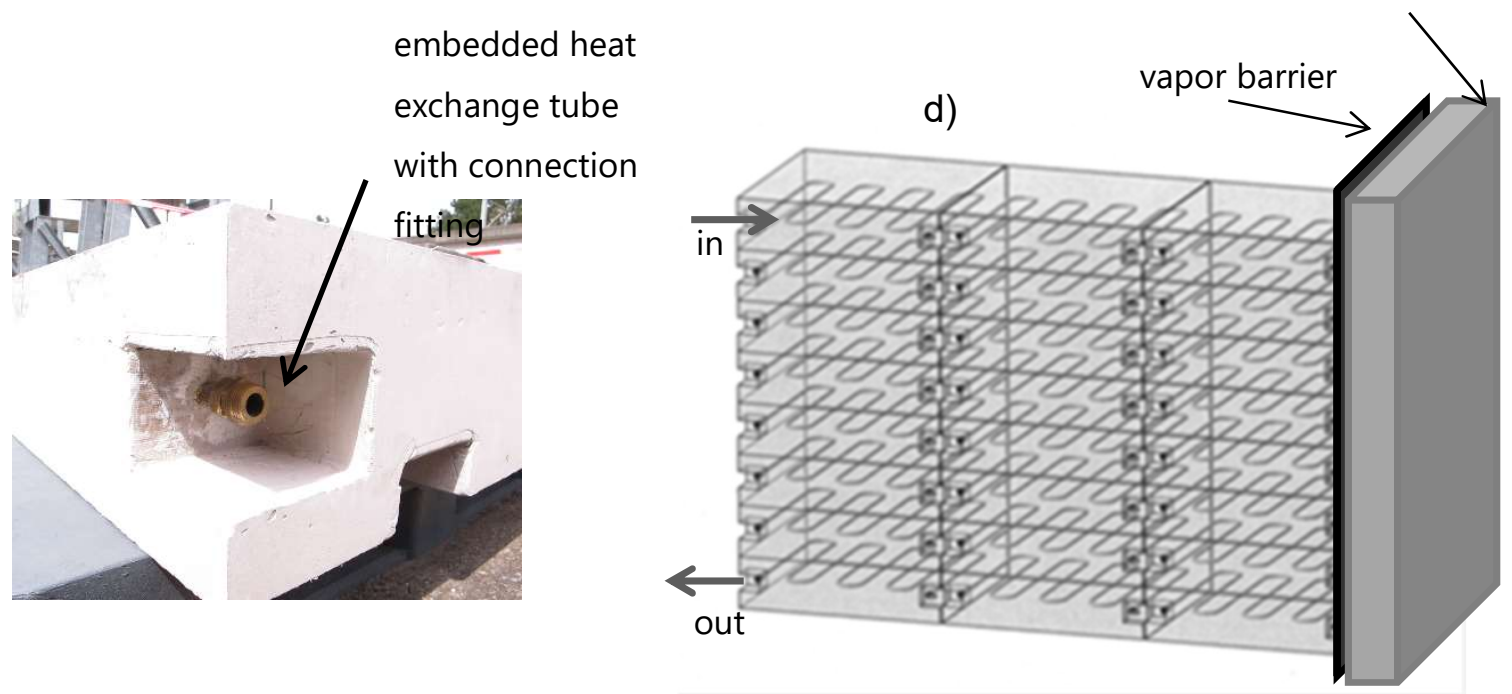

Fig. 8 Storage modules with embedded heat exchange tubes a) module $\left(0.25 \times 1 \times 1 \mathrm{~m}^{3}\right)$ with recesses for water addition (top) and transport/piling b) piled modules $\mathrm{c}$ ) fittings for tube connection d) general storage set-up with 3 columns and 8 levels.

\subsubsection{Implementation}

Locally a solar collector field of $20 \mathrm{~m}^{2}$ (flatbed collector Soltop COBRA Evo) placed on one side of the house was available. The concrete storage facility consisted of three main flow cycles (figure 9): a) solar cycle (solar liquid) b) heating cycle (water) c) ventilation cycle (air). The solar cycle, already pre-existent, served to collect the solar heat and store it into a large scale hot water tank of $9.3 \mathrm{~m}^{3}$. The thermal loading of this water tank was already automatized. To facilitate an easy connection, the concrete storage module with its heating cycle was connected to this hot water tank instead directly to the collector field. This limited the maximum loading temperature to about $90^{\circ} \mathrm{C}$, whereas significantly higher temperatures from a direct access of the collectors would have resulted. Furthermore, the hot water tank was thought to allow for a regular heat supply during loading. The limitation of drying temperature to $90^{\circ} \mathrm{C}$ also 
was chosen in order to prevent from decomposition of the ettringite to phases other than metaettringite as described in [34].

By means of the heating cycle, consisting of the connected copper tubes embedded into the CSA-concrete modules, hot water from the large water tank was pumped through the ettringite storage unit. In this way the CSA-concrete could be heated up for loading by drying and dehydration of the ettringite. In winter when the stored heat is recovered by water addition and rehydration of the ettringite, the heating cycle with the embedded copper tubes could collect the released heat and transport it to the large water tank which was connected to the heating system of the house.

Finally the air cycle serves as drying system during loading. Fresh air from the outside is exchanged in a counterflow heat exchanger with hot and humid air from the inside of the CSAstorage unit. The air flow (tubes with a diameter of $7.5 \mathrm{~cm}$ ) is forced by a ventilator blowing the fresh air into and through the unit. Wind speed could be adjusted and was set between 2.5 and $4.0 \mathrm{~m} / \mathrm{s}$ so that a flow rate of about $40-60 \mathrm{~m}^{3} / \mathrm{h}$ was possible. The air actually flowed through the transport recesses and some spare place left open between the three concrete piles and between the concrete piles and the vapor barrier. On the roof of the unit some additional spare space between the concrete and the water vapor barrier was provided as well to facilitate air collection by the ventilation tubes. The counterflow air-air heat exchanger (Klingenburg GS 16) guarantees the recovering of some heat of the outflowing air, including some condensation heat, by transferring it to the fresh and cold inflowing air. By heating up the inflowing air the relative humidity is lowered and hence the hot and dry air can uptake humidity when flowing through the hot CSA-storage unit. The air cycle actually is not closed. The big advantage of a closed air system would be that no $\mathrm{CO}_{2}$ can be transported to the CSA-concrete so that carbonation is not possible. However, a closed air circulation would require a condenser and sufficient cooling energy in order to dry the circulating air. Figure 10 shows the CSA concrete heat storage unit during construction and after the installation of the equipment. 


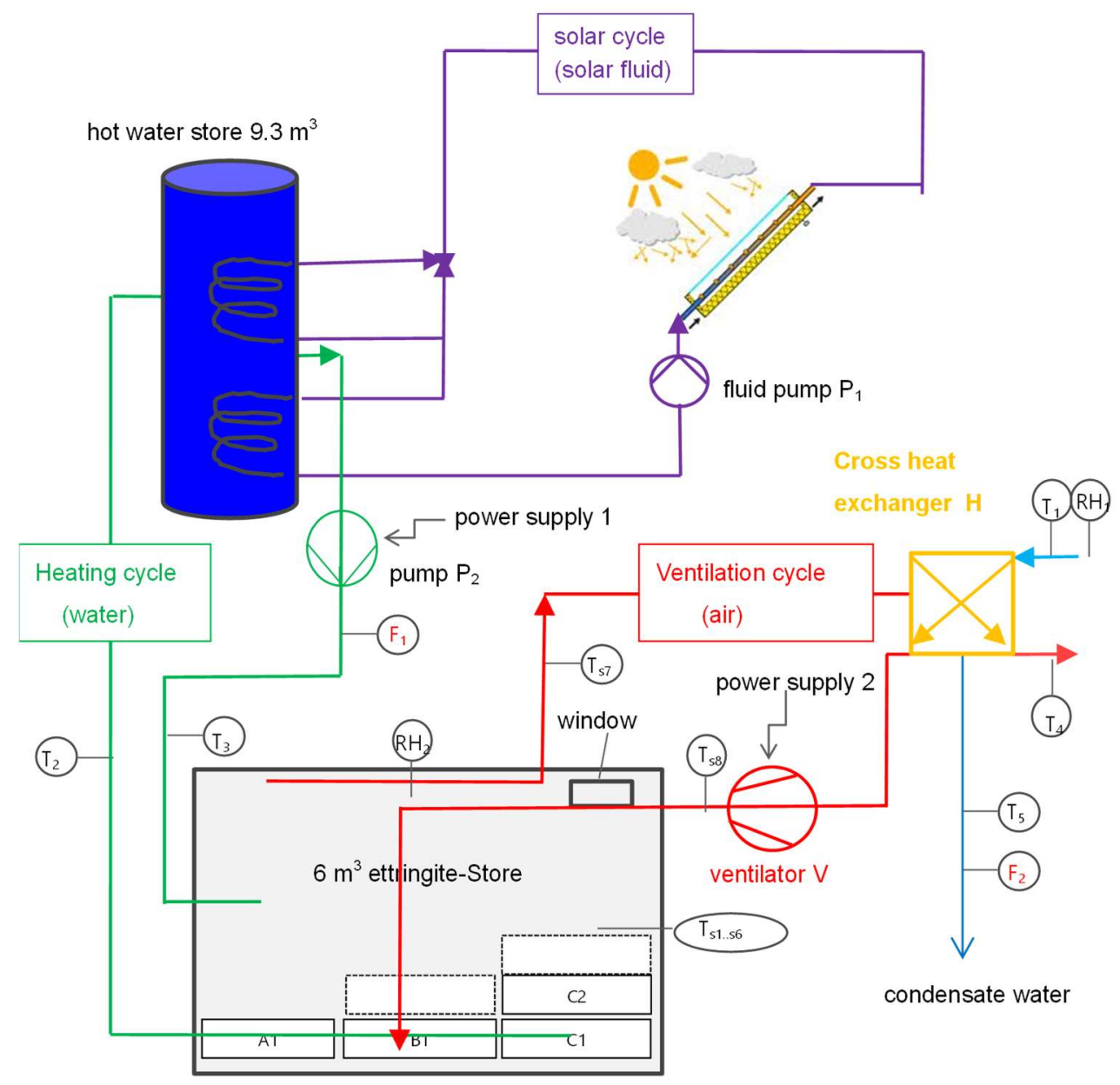

Fig. 9 Process and control scheme.

It was possible to execute a time schedule for the ventilator and the pump (heating cycle) by means of scheduling the power supply which furthermore was remote-controlled by a smartphone application. In this way silence regimes could be implemented and excess pumping during rainy or cloudy weather conditions was avoided. During the night neither the pump nor the ventilator was active. Ventilation also was stopped during noon because excess heating of the garage had to be avoided.

The temperature inside the ettringite-based heat storage unit was measured by means of thermocouples placed at 6 different positions on top and at the center of the modules A1, A5, C2, C6, B4 and on top but backside of module B4 (columns are labelled A,B,C; levels are numbered). Furthermore, temperature of inflowing and outflowing air $\left(\mathrm{TS}_{7} / \mathrm{TS}_{8}\right)$, the inflowing and outflowing hot water of the heating cycle $\left(T_{2} / T_{3}\right)$, the air in/out of the air heat exchanger $\left(T_{1} / T_{4}\right.$, $\mathrm{T}_{1}=$ ambient air) and finally the temperature of the condensate water were measured and logged by means of a data-logger. The relative humidity inside the storage unit and of the ambient air was also registered continuously and monitored by means of a web-application. 

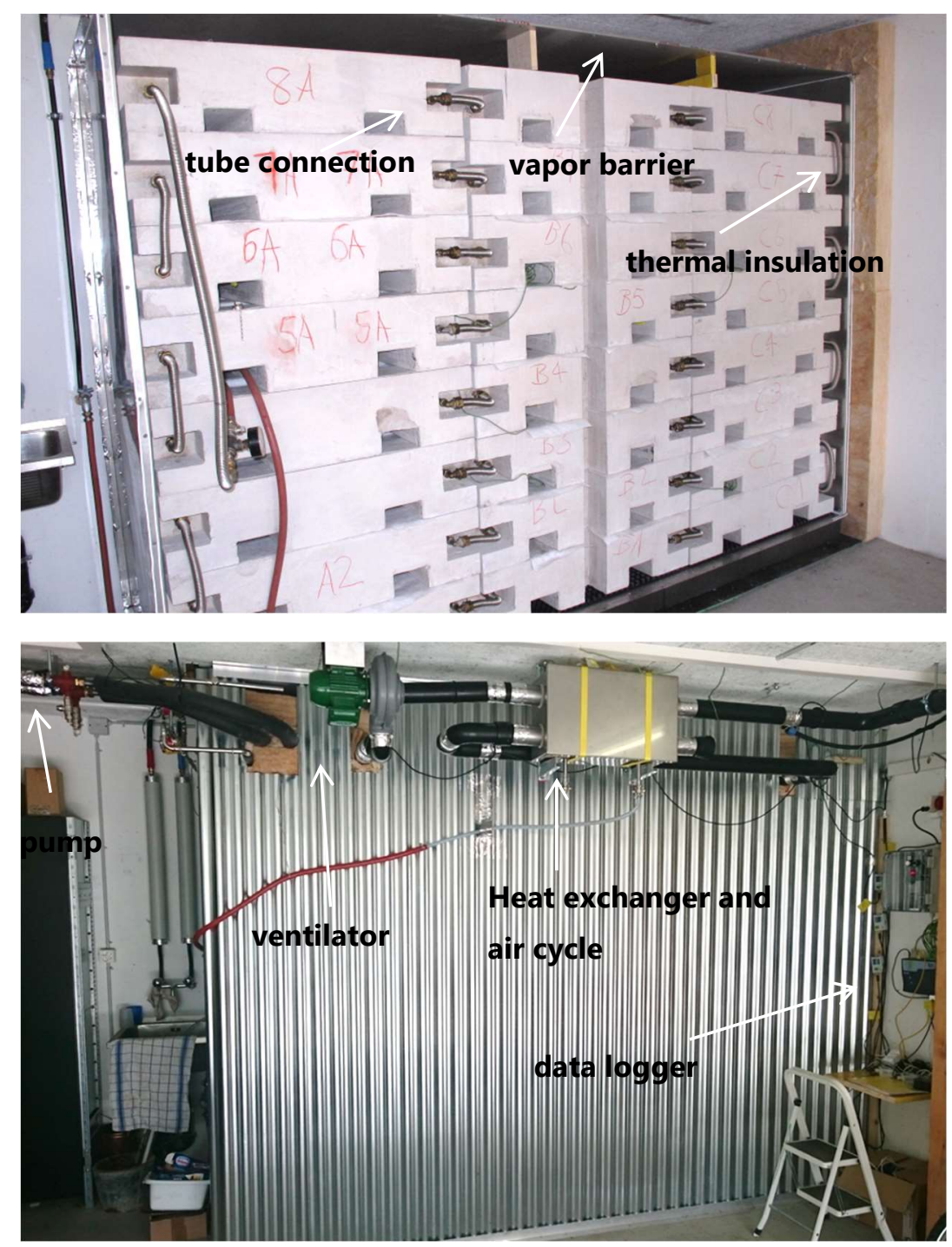

Fig. 10 CSA-Concrete based heat storage unit. Top: during construction with connected heat exchange tubes, bottom: final appearance with installed equipment

\subsubsection{Results}

\subsubsection{Loading summer 2016}

A first loading of the CSA-based storage unit was realized during summer 2016. A typical ventilation and pumping regime is provided in figure 11 . The temperature and water vapor pressure development as well as, for indication of solar irradiation, the photovoltaic output of a locally installed solar field is shown in figure 12 .

First heating up the storage unit (the heat capacity is estimated from the temperature behavior of the concrete storage unit to 0.4 to $0.55 \mathrm{kWh} / \mathrm{m}^{3} \mathrm{~K}$ ) was necessary. Then the remaining capillary water had to be evaporated as the modules had been stored at $90 \% \mathrm{RH} / 20^{\circ} \mathrm{C}$ prior to installation. Because of the ventilation time schedule, inner vapor pressure is fluctuating. The drying system by air ventilation obviously is much more efficient shortly after the interruption of the ventilation, but then stabilizes at relatively low vapor pressures of about 30-40 mbar. 


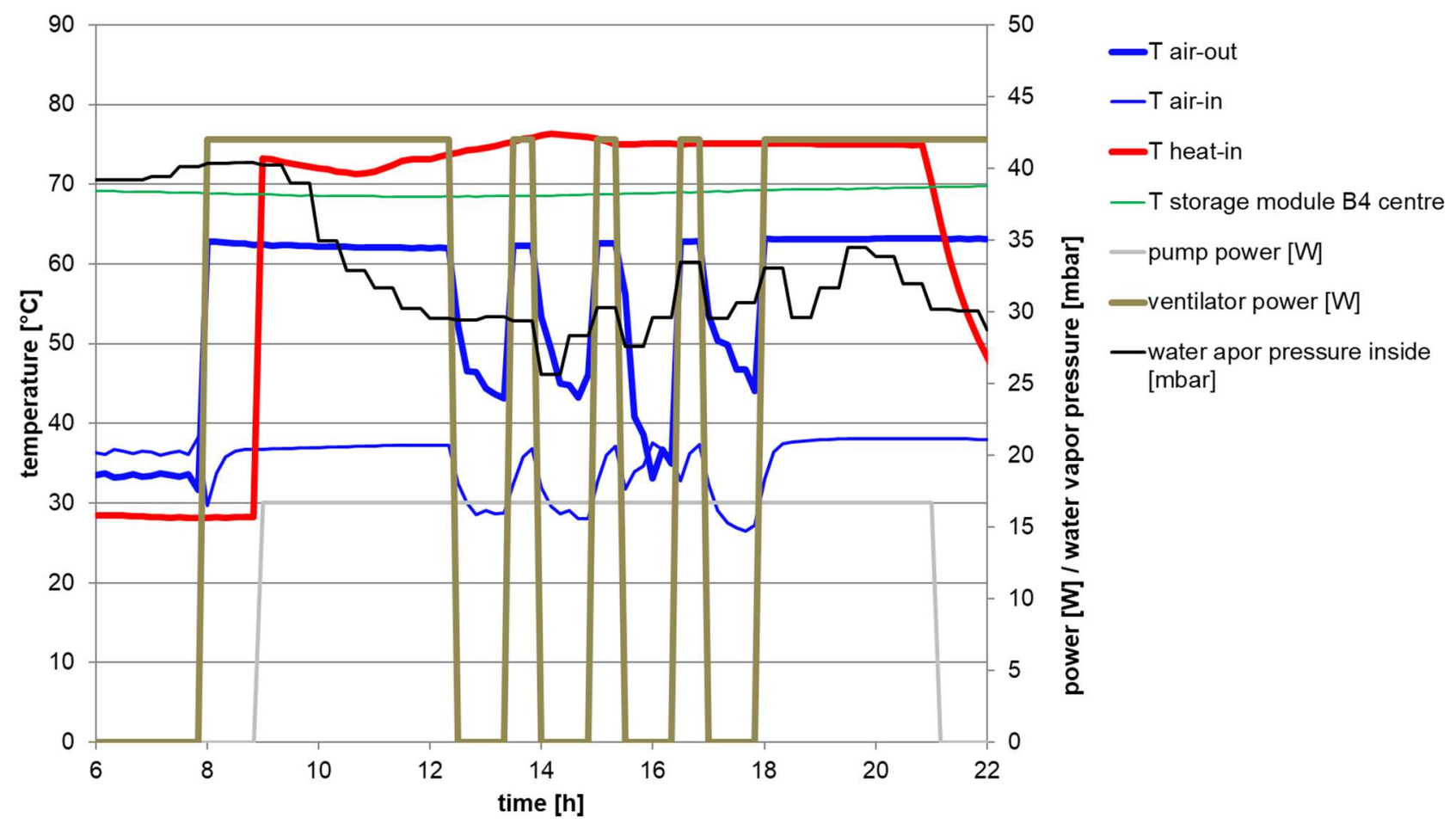

Fig. 11 Ventilation and pumping regime during one day ( 6 am to $10 \mathrm{pm})$. Turning the ventilator on lead to an air exchange rate of $41 \mathrm{~m}^{3} / \mathrm{h}$. Pumping (heating cycle) was at a water flow rate of about $0.4 \mathrm{~m}^{3} / \mathrm{h}$.

Over the whole loading (dehydration) period the water vapor pressure inside the storage unit remains significantly higher than the water vapor pressure of the fresh exchange air, meaning that drying/dehydration level of the CSA-concrete did not reach equilibrium stage. At the same time the temperature inside the storage unit could be lifted within some days to over $60^{\circ} \mathrm{C}$, but then further rise, especially above $70^{\circ} \mathrm{C}$ was difficult to obtain. The heat provided by the heating cycle was compensated by water evaporation. Furthermore the inflowing fresh air was of relatively low temperature of about $40^{\circ} \mathrm{C}$ only (figure 11), despite the air heat exchanger.

Temperature difference between inflowing and outflowing heating water was about $3-5^{\circ} \mathrm{C}$. The system itself was auto adjusting: the more energy that could be transferred to the storage unit, the higher was the evaporation rate. Higher temperature rises were possible during periods of sunny weather when the heat consumption of the hot water tank by the loading system of the concrete storage unit was compensated easily by the solar irradiation. Previously it was thought that the collector field of $20 \mathrm{~m}^{2}$ should be far enough for sufficient heat supply for loading the concrete unit. The main problem can be identified in the indirect access through a hot water tank. The maximum temperature of this tank and thus the inflow temperature to the concrete storage unit was limited to $90^{\circ} \mathrm{C}$. Hence the solar heat could not fully be transferred to the concrete storage unit, especially as the installed flatbed collectors delivered sufficiently high temperatures to reheat the hot water tank during a short (1-3 h) midday period and very good weather conditions only. During cloudy or foggy weather, the collector output fell quickly below the required temperatures to maintain the high heating input temperatures. Furthermore, the thermal losses (insufficient insulation of tubes, limited heat recovery through the air heat 
exchanger etc.) of the storage unit revealed an unexpected high heat loss. Nevertheless calculation from humidity and temperature data showed that about 650 liter of water could be removed from the storage unit in this first loading period (summer 2016).

Resaturation with 450 liter of water, added through the cascade system, lead to a temperature rise of maximum $14{ }^{\circ} \mathrm{C}$, only. This shows that mainly capillary water could be removed during this loading period and dehydration of the ettringite did not occur in sufficient manner. This is confirmed by the analysis of samples taken from the store just after the loading period as will be discussed later.

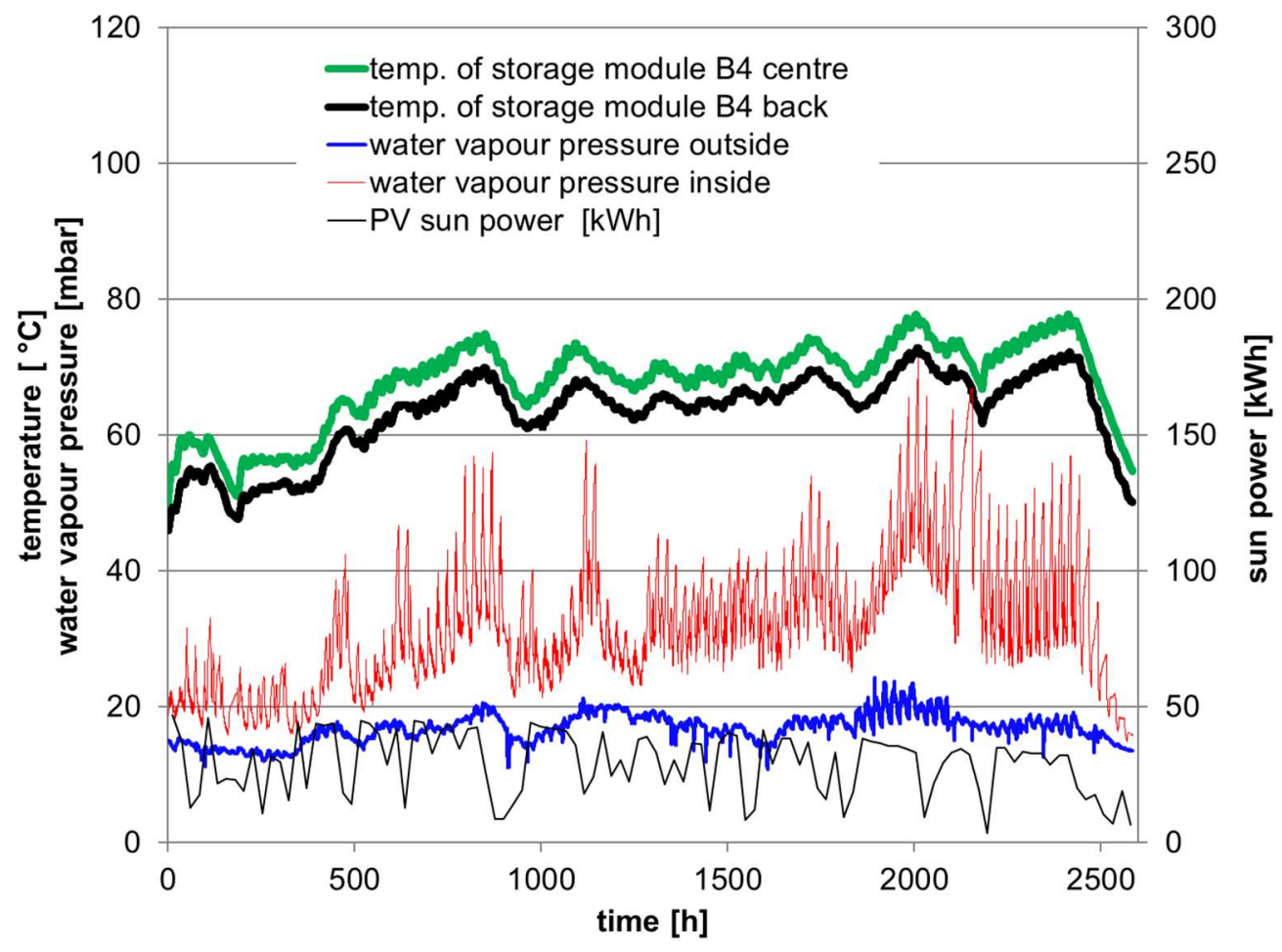

Fig. 12 Temperature and vapor pressure distribution during loading period 1 (summer 2016).

\subsubsection{Modification of the set-up and loading summer 2017}

The system hence had to be adapted in order to reach higher temperatures in the inside of the concrete store. However a complete redesign was not possible and the drawbacks of high thermal losses and indirect access of the heat collectors through the hot water tank could not be fixed. One possible solution was found in adapting the system slightly by adding an electric heater $(5 \mathrm{kV})$ to the heating cycle. Like this, higher input temperatures of up to $96^{\circ} \mathrm{C}$ could be generated. Electric power was delivered by a locally installed photovoltaic field equipped with a $5 \mathrm{kWh}$ battery. The system has the advantage that in this way also an alternative heat supply by usage of local excess solar power could be tested. It also has the advantage that the solar electricity output reveals to be more constant even during somewhat cloudy or foggy weather, while collector output under such conditions resulted to become insufficient because of low temperatures. 
For some reasons, especially for not passing critical degrees of over $90^{\circ} \mathrm{C}$ in the storage unit, a temperature where ettringite decomposition was thought to be initiated, the loop with the hot water tank acting as some kind of temperature control was maintained. Nevertheless this additional heating was very efficient. Hot water temperature could be lifted easily to above $90^{\circ} \mathrm{C}$. Electric heating hence had to be limited by a time schedule supported by a time scheme of the electric power supply, in order to protect the hot water tank from overheating.

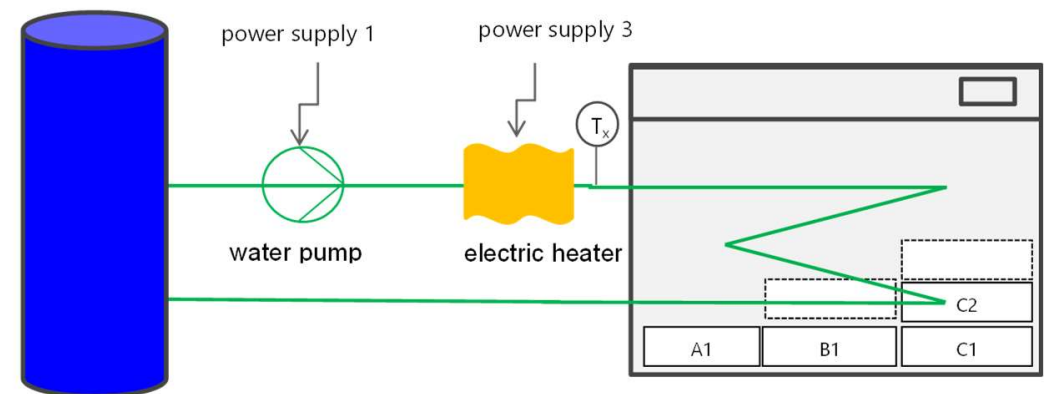

Fig. 13 Adaption with heater for loading period 2 (summer 2017).

Temperature and vapor pressure as measured during a second loading period (summer 2017) are plotted in figure 14. Temperatures quickly reached higher levels thanks to the additional heating system. It was possible to maintain CSA-concrete temperatures above $80^{\circ} \mathrm{C}$ for a relatively long period. Maximum temperature of the storage unit reached $83^{\circ} \mathrm{C}$. Higher temperatures could not be realized owing to the safety temperature limit of the large water tank. Vapor pressure at the beginning was somewhat higher than in the previous loading period due to higher temperatures and higher saturation level of the storage modules. With loading duration the vapor pressure continuously is reducing. During this second loading period a total of about 940 liters of water was removed from the CSA-storage facility. 


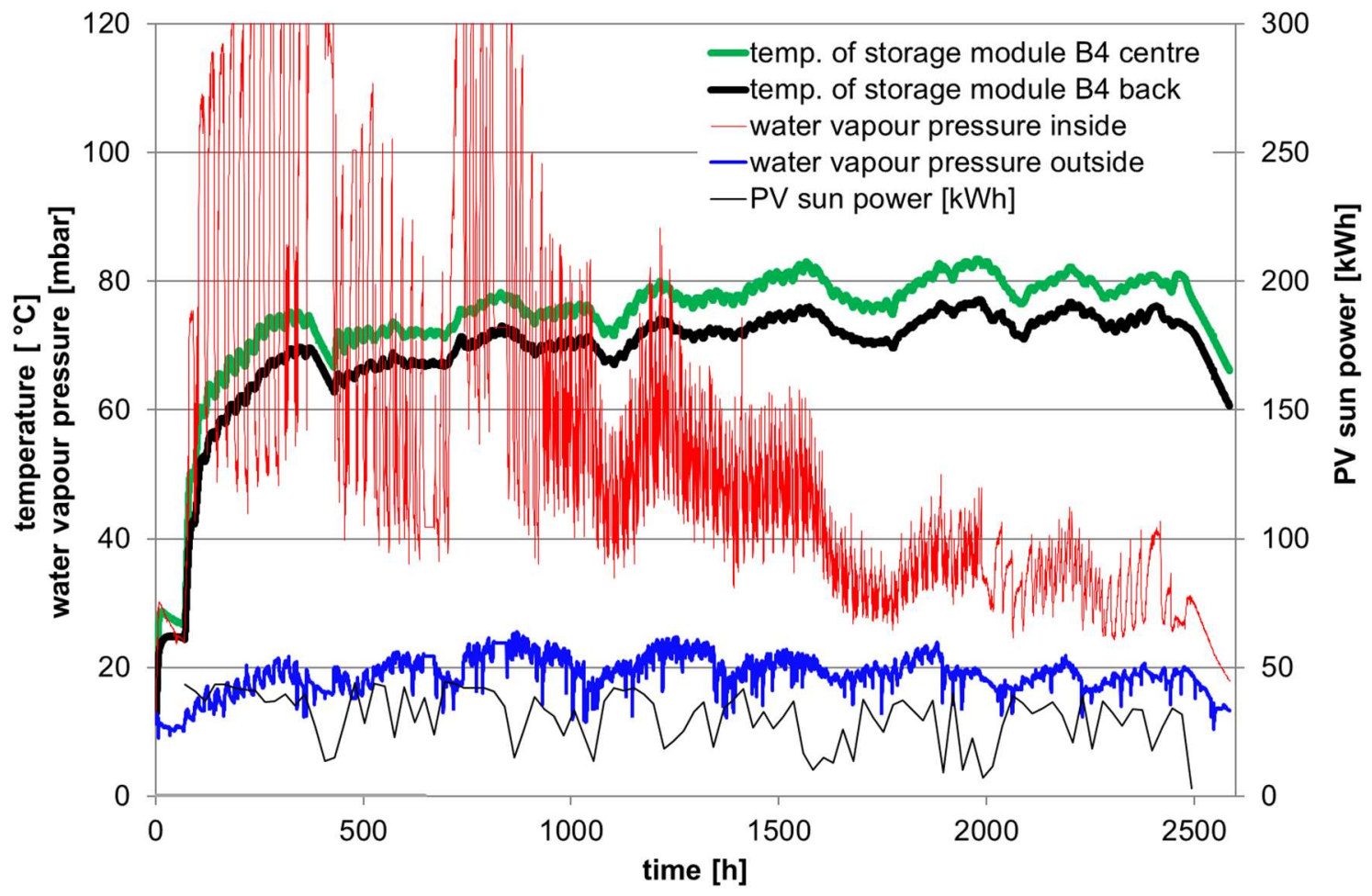

Fig. 14 Temperature and vapor pressure distribution during loading period 2 (summer 2017).

\subsubsection{Sampling}

After installation and after the loading in summer 2016 and 2017, samples were taken from the uppermost right front corner and their chemical phase composition was analyzed by means of X-ray diffraction (XRD) and thermogravimetry (TGA) (figure 15). The conversion of ettringite to meta-ettringite results in a reduction of the ettringite signal. The amount of ettringite already was significantly reduced after the first loading period (summer 2016), however still important amounts of ettringite were detected. Especially the thermogravimetric data reveals just little change between the phase composition before loading and after loading in this first period. The second loading period (starting after resaturation with 450 liter of water) was much more efficient. TGA and XRD show a significantly reduced ettringite content after this second loading period compared to the situation before the first loading period. However even after this period still some ettringite could be detected, indicating that the state of the storage facility still did not reach complete loading. Neither monosulphate nor katoite was detected.

Furthermore some slight carbonation was detected. The amount of carbonation actually did not significantly increase during the two loading cycles. This may be attributed to the low water vapor pressure during the loading periods when air and carbon dioxide is exchanged. Furthermore the water vapor flow out of the storage modules prevents from $\mathrm{CO}_{2}$ inflow into the CSAconcrete. Upon resaturation (deloading), the water saturation certainly reaches higher levels than during loading, so that carbonation would be more likely, but at this time the air is not exchanged and the $\mathrm{CO}_{2}$ that is consumed by the carbonation hence is not replaced. 
a)

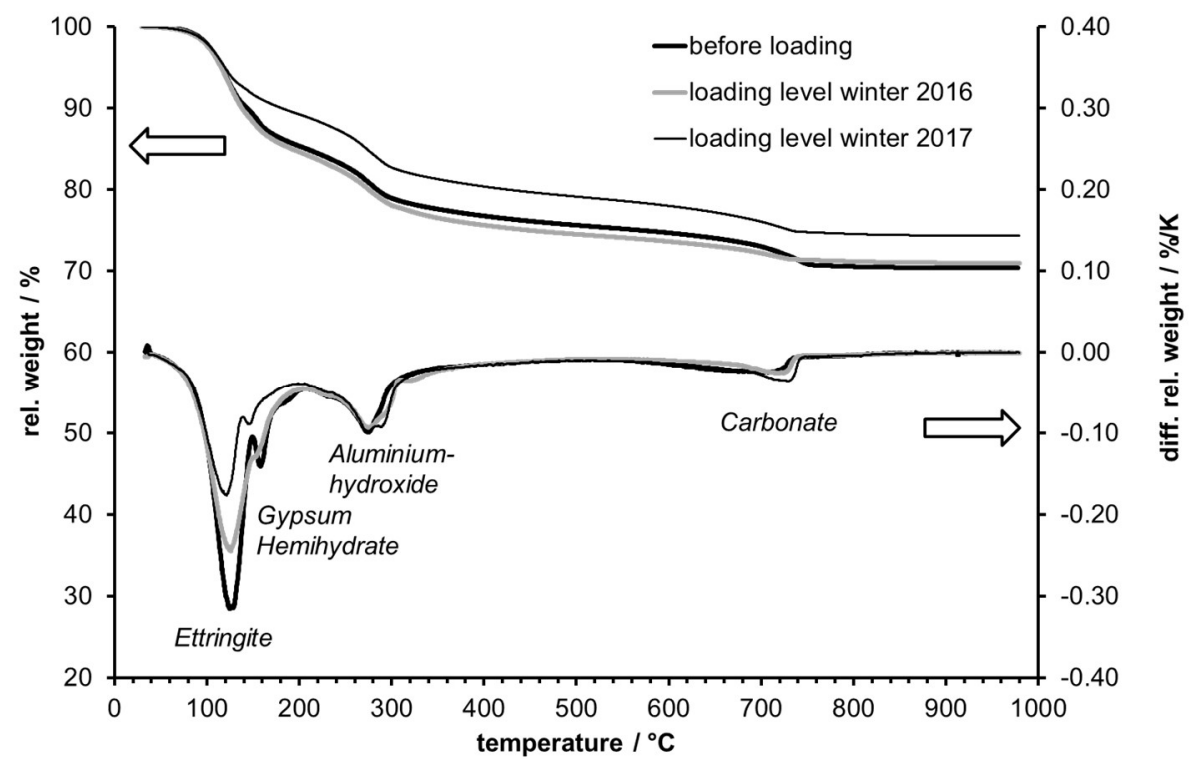

b)

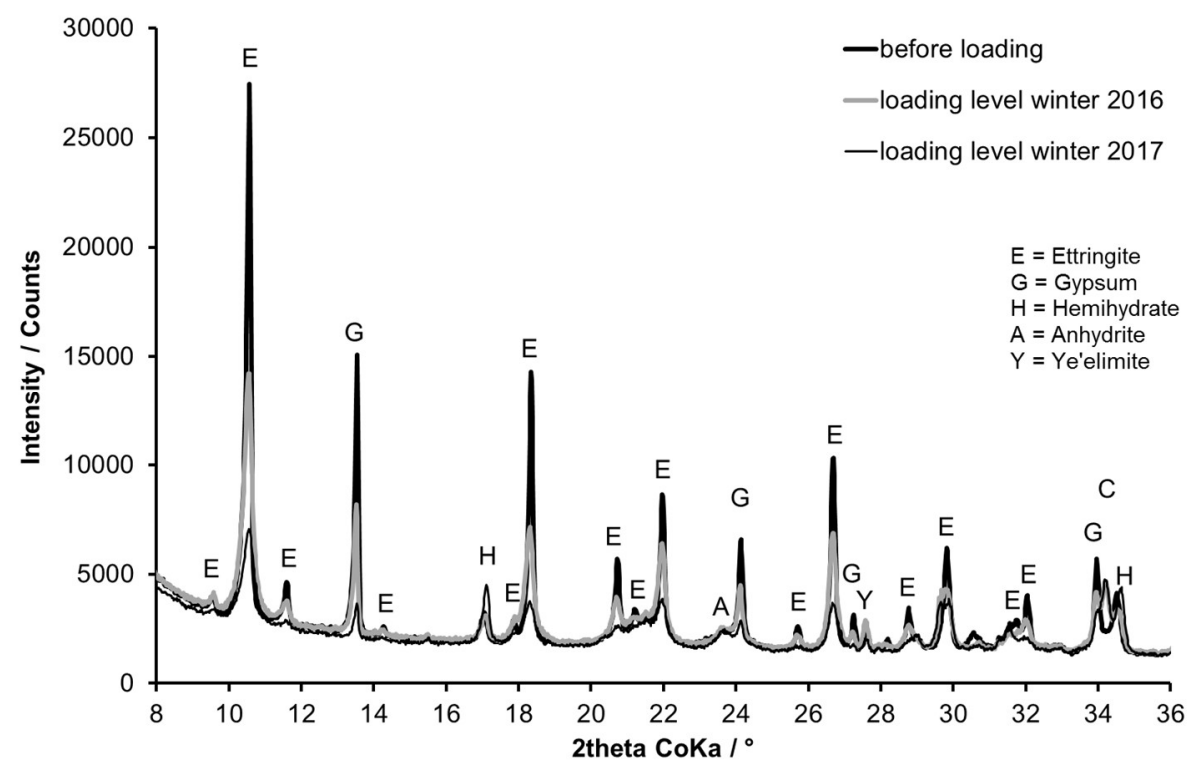

Fig. 15 Sample analysis by a) X-ray diffraction and b) thermogravimetry of samples taken after loading period 1 (loading level winter 2016) and after loading period 2 (loading level winter 2017). 


\subsubsection{Deloading winter $2017 / 2018$}

Resaturation after the second loading phase was done in January 2018. Water (water temperature was about $10^{\circ} \mathrm{C}$ ) was added through the cascade system in ten steps until it could be detected at the bottom of the storage facility. The total amount reached 820 liters. At 80 hours after the temperature in the storage facility was about $22{ }^{\circ} \mathrm{C}$ higher than prior to the water addition (figure 16). However, a much higher temperature rise was expected. The relative humidity in the storage unit increased quickly to above $93 \% \mathrm{RH}$. Contrary to the water addition after the first loading period, the temperature distribution in the storage unit varied strongly. No direct relation to the temperature level of the loading periods could be derived. This is again in contrast to the first reloading when a strong correlation with expected drying stage could be drawn. Such effects may be explained by a failure of the cascade type water addition system. Indeed after reloading the storage facility it was opened and serious cracking of the uppermost modules was observed (figure 17). It seems to be reasonable to assume that the cracks lead to an unwanted water flow and failure of the canal system, so that the dry concrete could not be equally and evenly resaturated and hence the stored heat could not be regained completely.

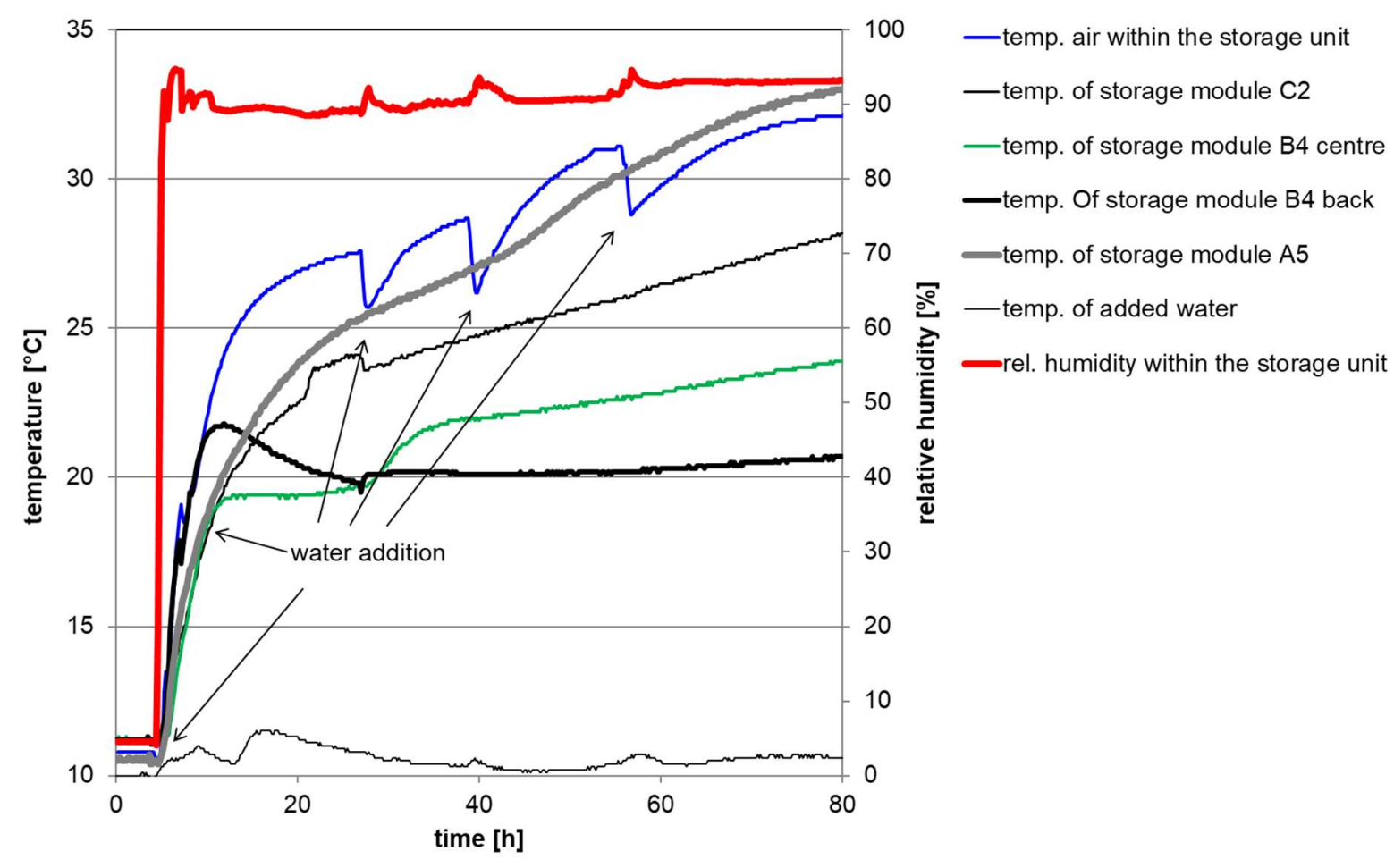

Fig. 16 Deloading by water addition after loading period 2 (winter 2017/2018). 


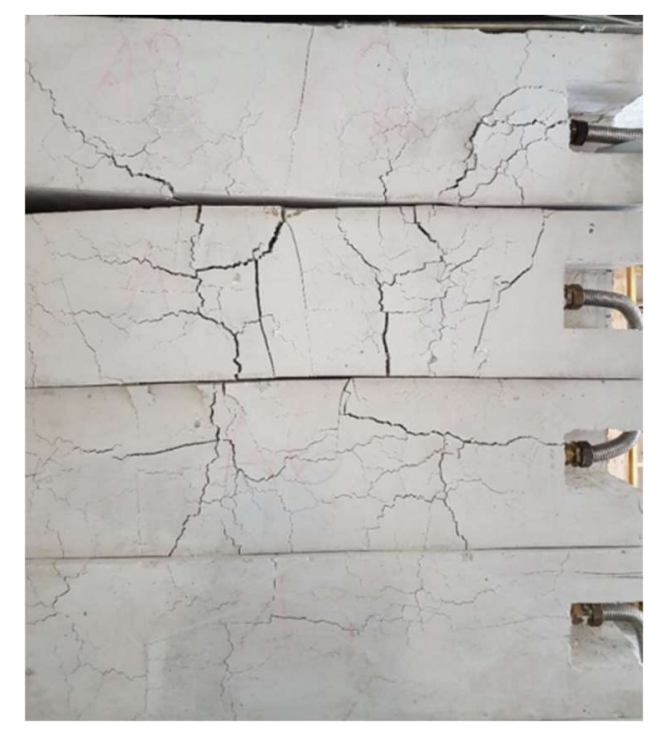

Fig. 17 Uppermost elements (row A) after resaturation with water (winter 2017/2018).

Cracking indicates unwanted decomposition of ettringite to monosulfate or katoite instead of dehydration to meta-ettringite. In TGA and XRD (figure 15) neither monosulfate nor katoite was detected. Sampling however, was at the surface where low humidities are achieved very quickly. It was not possible to take samples from the inside of the CSA storage unit as this would have required to dismantle the storage unit. Furthermore, the temperatures at the surface of the modules is lower than inside as the heating is from the embedded copper tubes. Both reduces the risk for ettringite decomposition. It hence shows that such decomposition may be prevented by a limitation of temperature and humidity during loading.

\section{Conclusions and outlook}

Special hardened cement pastes based on hydrated calcium sulfoaluminate cements (CSA), containing large amounts of ettringite, are proposed as seasonal heat storage material. The storage material and the storage principle are described in detail.

Furthermore, different prototypes made with CSA-based hardened cement pastes as storage material ranging from small size to large scale are studied. The complete system is tested on a modular $6 \mathrm{~m}^{3}$ energy storage unit. The construction details and the experiences acquired during two seasons with slightly different settings are described in detail and the main thermal characteristics during loading and deloading are presented.

Generally the achieved temperature level was far too low in order to allow complete dehydration of the ettringite. Nevertheless, cracking occurred. Different measures such as direct connection to the solar collector system, improved thermal insulation, improved air heat exchanger and its thermal insulation, larger inner surface and probably additional heater (such as installed in loading period 2) might help to overcome this problem. Another way would be to remove the 
water vapor by pumping and installation of a low vacuum around the storage modules. This would allow ettringite - meta-ettringite conversion at much lower temperature levels. Carbonation actually was not found to represent a serious problem during the 2 years test period, but it certainly also would take profit from a closed vacuum system.

The cascade water addition system seem to have failed and serious cracking of the CSAmodules was observed. Ettringite decomposition must have occurred, despite module temperatures of less than $90^{\circ} \mathrm{C}$ or owing to high core humidity. It seems that temperature rise was too fast at the beginning when the modules were saturated. A solution for this problem can be found in either an improved temperature control in a first drying phase when high humidity is present or generally lowering the necessary drying temperatures by lowering the vapor pressures through vacuum technology for instance. The water addition could be improved by subdivision of the concrete modules and putting them into containers which then are filled with water. On the other hand, it would generally be favorable to add water vapor instead of liquid water for deloading/resaturation. This would require a sufficient water vapor source like in other sorption based heat storage systems (e.g. based on zeolites or caustic soda) and furthermore requiring more complicated system elements. On the other hand sorption behavior of ettringite seems to be relatively slow. It might work fast enough at high vapor pressures only. Hence much higher surface would have to be provided to accelerate the sorption process. One option might be lowering the temperatures of the CSA-concrete modules (for instance by small volume heat pump) below the temperature of the added vapor in order to allow capillary condensation processes (Kelvin) based on the small pore diameters typically found for cement-based building materials.

Besides the seasonal storage of heat based on the dehydration and rehydration it is also possible to make use of the sensible (short/medium term) storage capacity based on relatively large mass and the heat capacity of the CSA-concrete $\left(0.3-0.55 \mathrm{kWh} / \mathrm{m}^{3} \mathrm{~K}\right.$, depending on saturation). A combination of latent and sensible heat storage options provided by the same storage unit could provide an interesting cost efficient option.

\section{Acknowledgement}

The authors would like to thank Markus Zumoberhaus (home owner Seelisberg) for fruitful discussions, his continuous support of the project and for allowing to place the ettringite storage unit in his residence. Thomas Spielmann, Thomas Zähringer (ZHAW) and Hans Markutt (Markutt heating $\mathrm{GmbH}$ ) are acknowledged for process engineering and technical assistance. Special thanks to the Empa's laboratory staff and Walter Trindler for their ideas and outstanding engagement when building the storage unit prototype and Swiss federal office for energy (SFOE) and Martin Bohnenblust (St. Gobain Isover AG) for financial support. 


\section{References}

[1] P. Pinel, C. Cruickshank, I. Beausoleil-Morrison, A. Wills, A review of available methods for seasonal storage of thermal energy in residential applications, Ren. Sust. Energy Rev., 15 (2011) 3341-3359.

[2] I. Dincer, On the energy storage and applications in buildings, Energy and Buildings, 34 (2002) 377-388.

[3] M.I. Alizadeh, M. Parsa Moghaddam, N. Amjady, P. Siano, M.K. Sheik-El-Eslami, Flexibility in future power systems with high renewable penetration: A review, Ren. Sust. Energy Rev. 57 (2016) 1186-1193.

[4] D. Heide, M. Greiner, L. von Bremen, C. Hoffmann, Reduced storage and balancing needs in a fully renewable European power system with excess wind and solar power generation, Ren. Energy, 36 (2011) 2515-2523.

[5] E. Ozrahat, S. Ünalan, Thermal performance of a concrete column as a sensible thermal energy storage medium and a heater, Ren. Energy, 111 (2017) 561-579.

[6] M.C. Alonso, J.Vera-Agullo, L. Guerreiro, V. Flor-Laguna, M.Sanchez, M. Collares-Pereira, Calcium aluminate based cement for concrete to be used as thermal energy storage in solar thermal electricity plants, Calcium aluminate based cement for concrete to be used as thermal energy storage in solar thermal electricity plants, Cem. Concr. Res. 82 (2016) 74-86.

[7] M. Koschenz, V. Dorer, Interaction of an air system with concrete core conditioning, Energy and Buildings 30 (1999) 139-145.

[8] G. Sang, Y. Cao, M. Fan, G. Lu, Y. Zhu, Q. Zhao, X. Cui, Development of a novel sulphoalumitate cement-based composite combing fine steel fibers and phase change materials for thermal energy storage, Energy and Buildings 183 (2019) 75-85.

[9] D. Hawes, D. Banu, D. Feldman, Latent heat storage in Concrete, Sol. Energy Mat. 10 (1989) 335-348.

[10] S.A. Memon, T.Y. Lo, S.A. Barbhuiya, W. Xu, Development of form-stable composite phase change material by incorporation of dodecyl alcohol into ground granulated blast furnace slag, Energy and Buildings 62 (2013) 360-367.

[11] A. Khudhair, M. Farid, A review on energy conservation in building applications with thermal storage by latent heat using phase change materials, Energy Conv. Manag. 45 (2004) 263-275.

[12] J. Kaufmann, F. Winnefeld (2011), Cement-based chemical energy store, Patent EP 2576720 B1, priority date 27.05.2010.

[13] F. Winnefeld, J. Kaufmann (2011), Concrete produced with calcium sulfoaluminate cement: a potential system for energy and heat storage. First Middle East conference on smart monitoring , assessment and rehabilitation of civil structures (SMAR 2011), Dubai, United Arab Emirates.

[14] L.J. Struble, PW Brown, Heats of dehydration and specific heats of compounds found in concrete and their potential for thermal energy storage, Solar Energy Materials, 14 (1986) 112.

[15] J. Pourchez, F. Valdivieso, P. Grosseau, R. Guyonneta, B. Guilhot, Kinetic modelling of the thermal decomposition of ettringite into metaettringite, Cement and Concrete Research, 36 (2006) 2054-2060.

[16] M.C.G. Juenger, F. Winnefeld, J. Provis, J. Ideker, Advances in alternative cementitious binders, Cem. and Concr. Res. 41 (2011) 1232-1243.

[17] E. Gartner, Industrially interesting approaches to "low- $\mathrm{CO}_{2}$ " cements, Cem. Concr. Res., 34 (9) (2004) 1489-1498.

[18] M. Ben Haha, F. Winnefeld, A. Pisch, Advances in understanding ye'elimite-rich cements, Cem. Concr. Res., (2019), submitted. 
[19] L. Zhang, M.Z. Su, Y.M. Wang, Development of the use of sulfo- and ferroaluminate cements in China, Adv. Cem. Res., 11 (1) (1999) 15-21.

[20] T. Wagner, D.A. Kulik, F.F. Hingerl, S.V. Dmytrieva, GEM-Selektor geochemical modelling package: TSolMod Library and data interface for multicomponent phase models, Canadian Mineralogist, 50 (5) (2012) 1173-1195.

[21] D.A. Kulik, T. Wagner, S.V. Dmytrieva, G. Kosakowski, F.F. Hingerl, K.V. Chudnenko, U.R. Berner, GEM-Selektor geochemical modeling package: revised algorithm and GEMS3K numerical kernel for coupled simulation codes, Computational Geosciences, 17 (1) (2013) 124.

[22] W. Hummel, U. Berner, E. Curti, F.J. Pearson, T. Thoenen, Nagra/PSI chemical thermodynamic data base 01/01, Radiochimica Acta, 90 (9-11) (2002) 805-813.

[23] B. Lothenbach, D.A. Kulik, T. Matschei, M. Balonis, L. Baquerizo, B. Dilnesa, G.D. Miron, R.J. Myers, Cemdata 18: A chemical thermodynamic database for hydrated Portland cements and alkali-activated materials, Cem. Concr. Res., 115 (2019) 472-506.

[24] F. Winnefeld, B. Lothenbach, Phase equilibria in the system $\mathrm{Ca}_{4} \mathrm{Al}_{6} \mathrm{O}_{12} \mathrm{SO}_{4}-\mathrm{Ca}_{2} \mathrm{SiO}_{4}-$ $\mathrm{CaSO}_{4}-\mathrm{H}_{2} \mathrm{O}$ referring to the hydration of calcium sulfoaluminate cements, RILEM Technical Letters, 1 (2016) 10-16.

[25] F. Winnefeld, S. Barlag, Calorimetric and thermogravimetric study on the influence of calcium sulfate on the hydration of ye'elimite, J. Therm. Anal. Calorim., 101 (3) (2010) 949957.

[26] Y. Jeong, C.W. Hargis, S.C. Chun, J. Moon, The effect of water and gypsum content on stratlingite formation in calcium sulfoaluminate-belite cement pastes, Constr. Build. Mater., 166 (2018) 712-722.

[27] C.W. Hargis, B. Lothenbach, C.J. Müller, F. Winnefeld, Further insights into calcium sulfoaluminate cement expansion, Adv. Cem. Res., (2019) in press.

[28] L. Pelletier-Chaignat, F. Winnefeld, B. Lothenbach, G. Le Saoût, C.J. Müller, C. Famy, Influence of the calcium sulphate source on the hydration mechanism of Portland cementcalcium sulphoaluminate clinker-calcium sulphate binders, Cement and Concrete Composites, 33 (5) (2011) 551-561.

[29] J.J. Wolf, D. Jansen, F. Goetz-Neunhoeffer, J. Neubauer, Mechanisms of early ettringite formation in ternary CSA-OPC-anhydrite systems, Adv. Cem. Res., (2018) 1-11.

[30] F. Winnefeld, L.H.J. Martin, C.J. Muller, B. Lothenbach, Using gypsum to control hydration kinetics of CSA cements, Constr. Build. Mater., 155 (2017) 154-163.

[31] Q. Zhou, F. Glasser, Thermal decomposition mechanisms of ettringite at $<120^{\circ} \mathrm{C}$. Cem. and Concr. Res., 31 (2001) 1333-1339.

[32] Ch. Hall, P. Barnes, A. Billimore, A. Jupe, X. Turrillas, Thermal decomposition of ettringite $\mathrm{Ca6}[\mathrm{Al}(\mathrm{OH}) 6] 2(\mathrm{SO} 4) 3 \cdot 26 \mathrm{H} 2 \mathrm{O}, \mathrm{J}$. Chem. Soc. Faraday Trans., 92(12) (1996) 2125-2129.

[33] N. Meller, K. Kyritsis, Ch. Hall, The hydrothermal decomposition of calcium monosulfoaluminate 14-hydrate to katoite hydrogarnet and $\beta$-anhydrite: An in-situ synchrotron X-ray diffraction study. J. of Solid State Chem., 182 (2009) 2743-2747.

[34] J. Kaufmann, F. Winnefeld, B. Lothenbach, Stability of ettringite in CSA cement at elevated temperatures, Adv. Cem. Res., 28 (Issue 4) 251-261.

[35] H. Taylor, C. Famy, K. Scrivener, Delayed ettringite formation, Cem. Concr. Res., 31(5) (2001) 683-693.

[36] Q. Zhou, F. Glasser, Kinetics and mechanism of the carbonation of ettringite, Adv. Cem. Res., 12 (3) (2000) 131-136.

[37] G. Le Saoût, V. Kocaba, K. Scrivener, Application of the Rietveld method to the analysis of anhydrous cement, Cem. Concr. Res., 41 (2) (2011) 133-148.

[38] G. Álvarez-Pinazo, A. Cuesta, M. García-Maté, I. Santacruz, E.R. Losilla, A.G. de la Torre, L. León-Reina, M.A.G. Aranda, Rietveld quantitative phase analysis of yeelimite-containing cements, Cem. Concr. Res., 42 (7) (2012) 960-971. 
[39] R. Snellings, X-ray powder diffraction applied to cement, in: K. Scrivener, R. Snellings, B. Lothenbach (Eds.) A Practical Guide to Microstructural Analysis of Cementitious Materials, CRC Press, Boca Raton (FL, USA), London (UK) and New York (NY, USA), 2015, pp. 107176.

[40] L. Wadsö, Applications of an eight-channel isothermal conduction calorimeter for cement hydration studies, Cement International 5 (2005) 94-101.

[41] L. Pelletier, F. Winnefeld, B. Lothenbach, The ternary system Portland cement-calcium sulphoaluminate clinker-anhydrite: hydration mechanism and mortar properties, Cem. Concr. Comp., 32 (7) (2010) 497-507.

[42] K. Ndiaye, S. Ginestet, M. Cyr, Experimental evaluation of two low temperature energy storage prototypes based on innovative cementitious material, Applied Energy

217 (2018) 47-55.

[43] J. Kaufmann, Pore space analysis of cement-based materials by combined Nitrogen sorption-Wood's metal impregnation and multi-cycle mercury intrusion, Cem. Concr. Comp., 32 (2010) 514-522.

[44] C. Villani C., R. Loser, M.J. West, C. Di Bella, P. Lura, W.J. Weiss, An inter lab comparison of gas transport testing procedures: Oxygen permeability and oxygen diffusivity, Cem. and Concr. Comp., 53 (2014) 357-366. 